BOGUSŁAW KRASNOWOLSKI

Uniwersytet Papieski Jana Pawła II w Krakowie

\title{
UKŁADY PRZESTRZENNE MIAST PRYWATNYCH W MAEOPOLSCE. WYBRANE PRZYKŁADY
}

Zarys treści: Problematykę omówiono na podstawie wybranych miast prywatnych: Tarnowa, Bobowej, Gorlic, Szymbarku, Chrzanowa, Książa Wielkiego, Dukli. Lokowane w XIV w., są charakterystycznymi dla ówczesnej fazy urbanizacji ośrodkami średniej lub niewielkiej skali. Istotne elementy przeprowadzonych analiz to: związek miasta z lokacyjnymi wsiami (w ramach jednolicie zagospodarowywanego kompleksu osadniczego), relacje między układem urbanistycznym a siedzibą właściciela, wypełnianie układu urbanistycznego zabudowa, w tym fundacjami właściciela, akcentującymi pozycję rodu.

The content outline: The issue is discussed on the basis of selected private towns: Tarnów, Bobowa, Gorlice, Szymbark, Chrzanów, Książ Wielki, Dukla. These towns, founded in the $15^{\text {th }}$ century, are characteristic of that time's phase of urbanisation, dominated with middle- and small-sized centres. The crucial elements of the analyses carried out in the paper are: links of the town to its surrounding villages (within a uniformly developed settlement complex), relationship between the urban layout and the residence of the owner, filling out urban layout with infrastructure, including the buildings founded by the owner, emphasising the position of the family.

Słowa kluczowe: Małopolska, miasta prywatne, kolonizacja na prawie niemieckim, urbanizacja, urbanistyka, ruralistyka, architektura średniowieczna i nowożytna

Keywords: Lesser Poland, private towns, colonisation under German law, urbanisation, urbanism, rural planning, medieval and modern architecture

Liczba inicjatyw osadniczych małopolskiego rycerstwa w okresie średniowiecznej kolonizacji miejskiej i wiejskiej ustępowała poczynaniom monarchów, dorównując aktywności duchowieństwa. Inicjatywy rycerstwa były stosunkowo późne, w zasadzie wiązały się z kształtowaniem elit możnowładczych za Władysława Łokietka i Kazimierza Wielkiego. 
Nie wydały większych założeń urbanistycznych: wiek XIV to okres uzupełniania sieci osadniczej o miasta małe i średnie.

Odrębnym problemem są miasta nowożytne, niemal wyłącznie prywatne. Istotna różnica $\mathrm{w}$ rozplanowaniu większości z nich $\mathrm{w}$ stosunku do miast średniowiecznych polega na dominacji przesłanek ideowych i estetycznych nad zdecydowanie dominującymi w średniowieczu gospodarczymi i użytkowymi.

Rozważania ograniczono do kilku wybranych, prywatnych miast średniowiecznych, uwzględniając ich przekształcenia architektoniczne w dobie nowożytnej.

Różnice $\mathrm{w}$ programach i kompozycjach między średniowiecznymi miastami prywatnymi a monarszymi nie miały ani pierwszorzędnego znaczenia, ani wyłączności. Elementem różnicującym bywała siedziba pana feudalnego - nieobca większym miastom monarszym i biskupim, w prywatnych, które były centrami dóbr, stawała się reguła. Fundacje kościelne akcentowały (często wtórnie) rangę rodu właściciela, stając się miejscem pochówków, niekiedy mauzoleum. W dobie nowożytnej pojawiały się kwartały żydowskie.

Zarówno miasta prywatne, jak monarsze bywały związane z kompleksami osadniczymi obejmującymi liczne wsie, komasowanie terytoriów w ręku jednego właściciela (rodu) należało do istotnych elementów zagospodarowywania włości. W dotychczasowych badaniach brak jest analiz przestrzennych, w tym modularnych, odnoszących się do zagospodarowania wielkich kompleksów osadniczych. Sytuację taką udokumentowano na Podhalu ${ }^{1}$, gdzie jednak inicjatywa - wraz z lokacjami miast Nowego Targu i Krościenka - pochodziła od króla, a wsie rycerskie i klasztorne stanowiły tylko pojedyncze ogniwa w łańcuchu. Nie ulega jednak wattpliwości, że powiązane ze sobą funkcjonalnie i planistycznie zespoły wsi zgrupowane przy mieście i rezydencji właściciela, osadzane w podobnym okresie i podobnie rozwiazzywane (zapewne często z zastosowaniem tych samych miar), dotyczyły także dóbr prywatnych, a prowadzenie badań wymaga konfrontowania danych wynikajacych ze źródeł różnego rodzaju z analizami przestrzennymi².

Częstym zjawiskiem - zwłaszcza w dobrach prywatnych - było poprzedzanie lokacji miasta lokacją wsi, z której później miasto wydzielano tak, by uniknąć konfliktów własnościowych.

${ }^{1}$ B. Krasnowolski, Zasady lokacyjnego rozmierzenia wsi podhalańskich miedzy Nowym Targiem a Krościenkiem, w: Późne średniowiecze w Karpatach polskich, red. J. Gancarski, A. Muzyczuk, Krosno 2007, s. 123-137.

2 T. Zarębska, Badania historyczno-urbanistyczne metoda analiz przestrzennych, KHKM, t. 43, 1995, nr 1, s. 15-32. 
Średniowieczne lokacyjne miasta prywatne można dzielić na grupy według rozmaitych kryteriów. Tu przyjęto podział na podstawie relacji zachodzących między miastem a siedzibą właściciela i kompleksem dóbr, dla których owa siedziba stanowiła centrum dyspozycyjne. Pierwsza grupa to miasta, których lokacji dokonywano w ramach jednego chociaż często rozciagniętego na lata - procesu osadzania okolicznych wsi i kształtowania siedziby właściciela. Drugą stanowią miasta, których lokacja nie była jednoczesna z ukształtowaniem siedziby. Trzecią - małe miasta o drugorzędnej roli w rodowych dobrach, niewymagające przeto obecności siedziby właściciela.

Przykładem miasta prywatnego stanowiacego - wraz z warowną siedzibą właściciela - centrum dóbr ziemskich, założonego w obrębie nieco wcześniej lokowanych wsi - jest Tarnów ${ }^{3}$ Spicymira Leliwity ${ }^{4}$, który od lat 20. XIV w. konsekwentnie pozyskiwał i zagospodarowywał dobra położone m.in. w dolinie Dunajca. Kompleks ten już za jego życia dzielił się na dwie części: południową pod osłoną zamku Melsztyn i północną zwiazaną z Tarnowem.

Przed 1327 r. w posiadaniu Spicymira znalazła się część, a w 1327 r. cała wieś Tarnów Wielki. Udzielone wówczas przez biskupa zwolnienia od dziesięcin dla wsi, które Spicymir miał zamiar osadzać, świadcza o szerokiej skali akcji kolonizacyjnej, której celem było ukształtowanie zwartego kompleksu dóbr ${ }^{5}$. Rok później Władysław Łokietek nadał mu sasiedni Tarnów Mały i przeniósł obie wsie na prawo niemieckie 6 . W 1330 r. król zezwolił Spicymirowi na lokację miasta na prawie niemieckim w obrębie Tarnowa Wielkiego oraz na przeniesienie na prawo niemieckie okolicznych wsi ${ }^{7}$; jak wynika z dokumentu Kazimierza Wielkiego z $1344 \mathrm{r} .^{8}$ były to m.in. położone w bezpośrednim sasiedztwie Skrzyszów, Łękawica, Szynwałd (Mnich).

${ }^{3}$ Analiza źródeł pisanych: S. Mateszew, F. Sikora, Osadnictwo i stosunki własnościowe w regionie tarnowskim do końca XVI wieku, w: Tarnów. Dzieje miasta i regionu, t. 1, red. F. Kiryk, Z. Ruta, Tarnów 1981, s. 106-107; F. Kiryk, Miasta regionu tarnowskiego do końca XVI w., w: tamże, s. 216.

${ }^{4}$ W. Dworzaczek, Leliwici tarnowscy. Z dziejów możnowładztwa małopolskiego, wiek XIV-XV, Warszawa 1971, s. 11, 65-67.

${ }_{5}^{5}$ Archiwum ksiażąt Lubartów-Sanguszków w Stawucie, t. 2, wyd. Z.L. Radzimiński, B. Gorczak, Lwów 1888 (dalej: AS II), nr 10; Kodeks dyplomatyczny katedry krakowskiej św. Wacława, t. 1, wyd. F. Piekosiński, Kraków 1879, s. 183; W. Dworzaczek, dz. cyt., s. 78.

${ }^{6}$ AS II, nr 11; W. Dworzaczek, dz. cyt., s. 78.

7 AS II, nr 12; AGZ, t. 5, Lwów 1875, nr 1; W. Dworzaczek, dz. cyt., s. 78.

${ }^{8}$ AS II, nr 16. 
Il. 1. Tarnów, lokacje wiejskie (Mały i Wielki Tarnów, 1328) i miejska (1330); rozmierzenie ról i centra osadnicze: 1 - miasto Tarnów, 2 - wieś Wielki Tarnów, 3 - wieś Mały Tarnów, 4 - zamek na Górze św. Marcina, 5 - domniemana sytuacja siedziby wójtowskiej; oprac. własne autora.

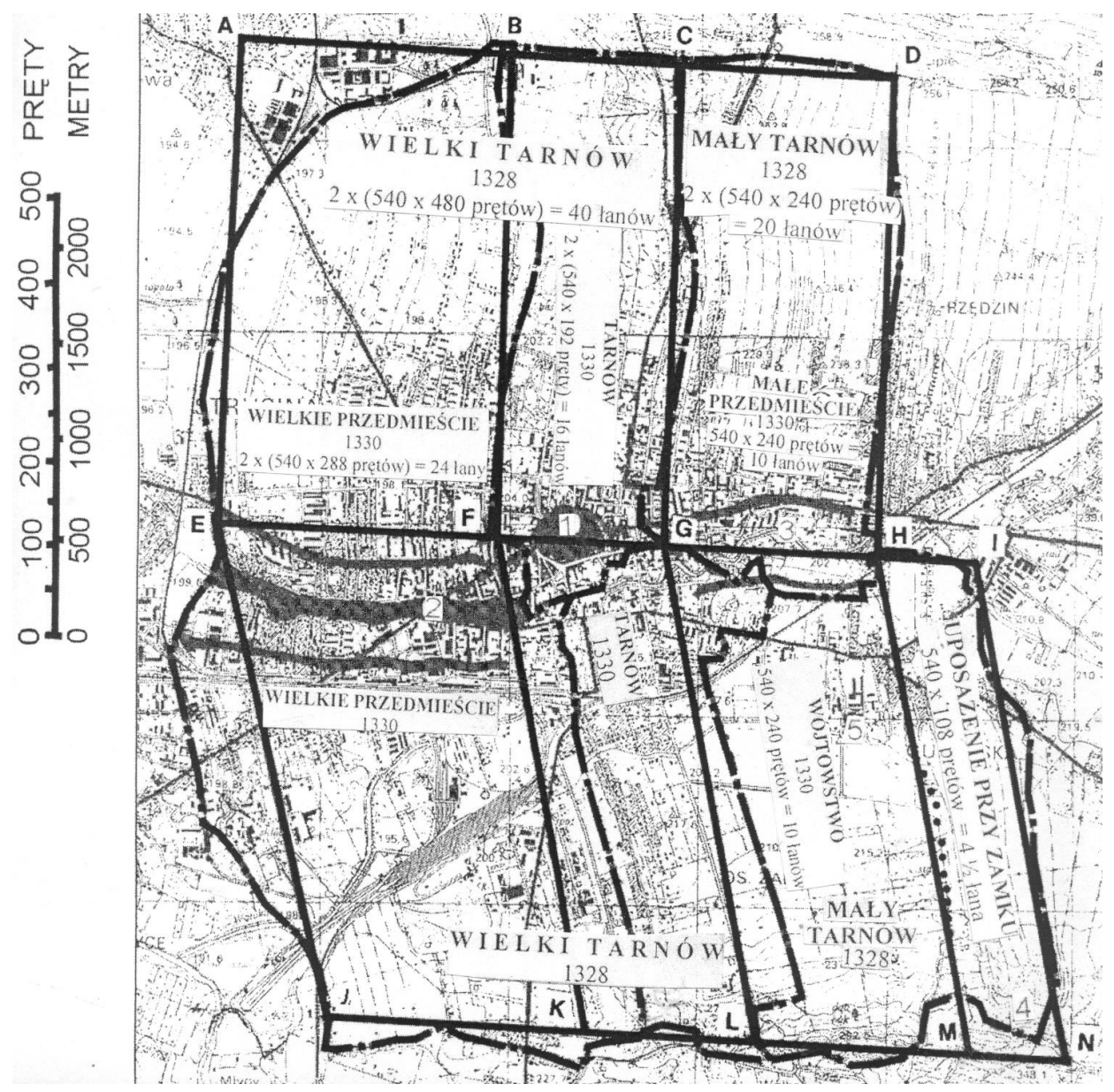

Analiza przestrzenna, wraz z ustaleniem zastosowanych miar ${ }^{9}$, pozwala określić zasady lokacyjnego rozmierzenia układów przestrzennych, następującego w dwóch okresach.

Pierwszy (il. 1) to przeniesienie obu wsi na prawo niemieckie. Tarnów Wielki odpowiadał późniejszemu Przedmieściu Wielkiemu

${ }^{9}$ Stopa $=0,2983 \mathrm{~m}$, pręt $=10$ stóp $(4,473 \mathrm{~m})$ i sznur $=150$ stóp $(44,73 \mathrm{~m})$; T. Zagrodzki, Regularny plan miasta średniowiecznego a limitacja miernicza, Warszawa 1962; B. Krasnowolski, Lokacyjne układy urbanistyczne na obszarze Ziemi Krakowskiej w XIII i XIV wieku, cz. 2, Kraków 2004, s. 247-253. 
Il. 2. Tarnów, rekonstrukcja lokacyjnego rozmierzenia centrum według Tadeusza Zagrodzkiego; za: B. Krasnowolski, Lokacyjne uktady urbanistyczne na obszarze Ziemi Krakowskiej w XIII i XIV wieku, cz. 2, Kraków 2004, s. 250.

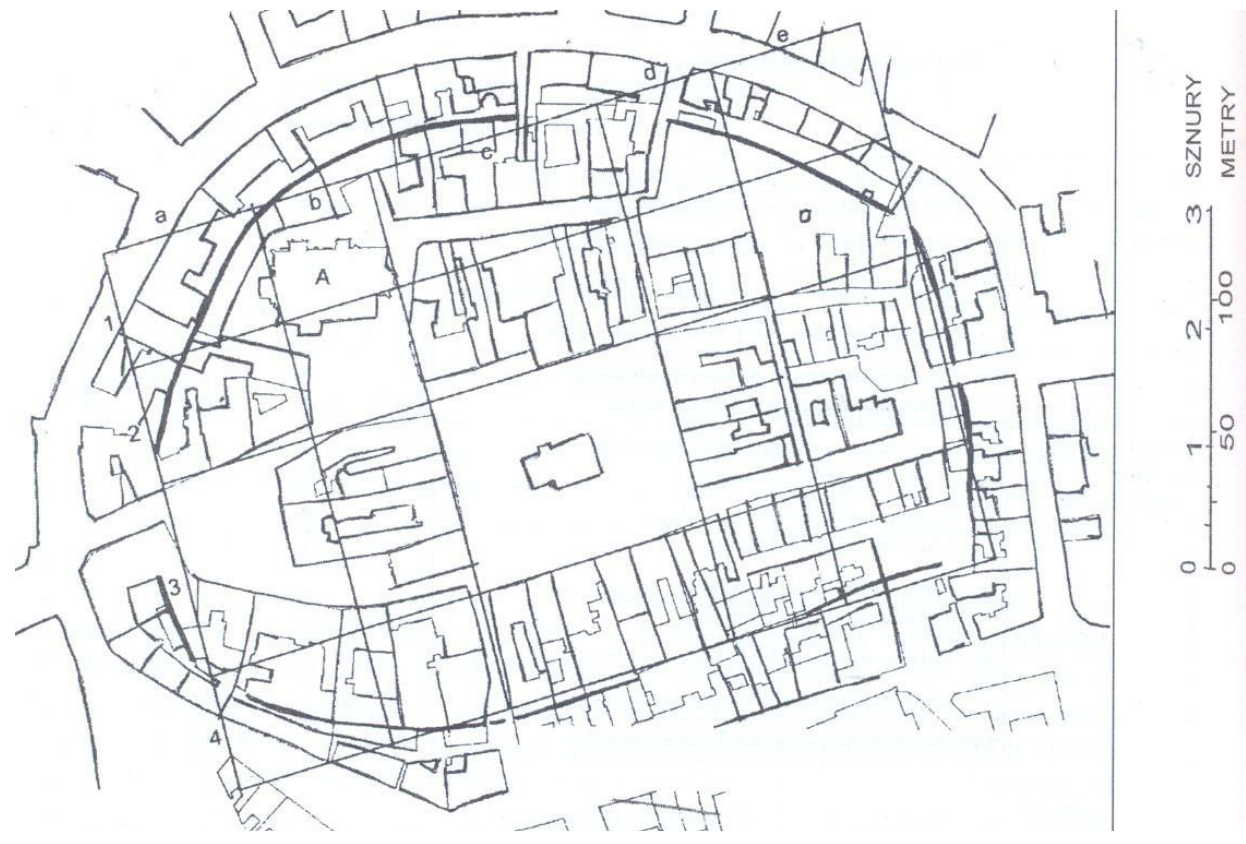

(Strusinie) z późniejszym miastem, Mały - Przedmieściu Małemu (Grabówce i Gumniskom); czytelne sa nawsia, rozłóg ról o kierunku północ-południe, granice można wpisać w czworoboki o powierzchniach 40 i 20 łanów frankońskich ${ }^{10}$.

Okres drugi to lokacja miasta w 1330 r. Ze wschodniej części areału Wielkiego Tarnowa wydzielono uposażenie miejskie (16 łanów). Południowy kompleks ról dawnego Małego Tarnowa (10 łanów, późniejsze Gumniska) zapewne przeznaczono na uposażenie wójtowskie (przekazane w 1363 r. właścicielowi miasta ${ }^{11}$ ). Można się domyślać, że w rejonie dzisiejszego, późnoklasycystycznego pałacu Sanguszków, jako właścicieli Tarnowa, znajdowała się lokacyjna siedziba wójtowska. Centrum osadnicze (il. 2) wytyczono na niezasiedlonym wzniesieniu.

10 Łan frankoński $=12.960$ prętów kwadratowych (kopanek, pólek); H. von Loesch, Die frankische Hufe, „Zeitschrift des Vereins für Geschichte Schlesiens” 61, cz. 1-2, 1927, 1929; J. Szymański, Nauki pomocnicze historii, Warszawa 1983, s. 173; A. Dunin-Wasowicz, Pomiar gruntu $w$ Koronie $w X V-X V I I I ~ w .$, Warszawa 1994, s. 68; B. Krasnowolski, Lokacyjne uktady..., cz. 1, s. 140-142. Uprawianie roli z zastosowaniem pługa wymagało wydłużonych proporcji łanów, np. 24 x 540 pręty.

${ }^{11}$ KDMłp., t. 3, wyd. F. Piekosiński, Kraków 1887, nr 763; F. Kiryk, Miasta..., s. 217. 
Skromny program kościoła parafialnego, wzmiankowanego po raz pierwszy w 1346 r. $^{12}$, być może od początku wzbogacała kaplica Świętego Krzyża, domniemane dzieło królewskiego warsztatu budowlanego ${ }^{13}$. Linię obronną początkowo tworzył kamiennym mur ${ }^{14}$.

Jednocześnie na Górze Świętego Marcina ${ }^{15}$ powstał zamek Spicymira ${ }^{16}$, kontrolujący rozległy teren, wzmiankowany od $1328 \mathrm{r}^{17}{ }^{17}$, z kaplica dysponująca od $1331 \mathrm{r}$. prawami parafialnymi ${ }^{18}$. Zamek został „wpisany” $\mathrm{w}$ pas uposażenia o powierzchni $4 \frac{1}{2}$ łana, przyległy od wschodu do modularnego czworoboku ról wójtowskich, „wykrojony” z części Skrzyszowa. Nie można wykluczyć, że pierwotnie (?) zamek miał sąsiadować z miastem. Autor kroniki bernardyńskiej z 1656 r. uważał, że klasztor ten zajął miejsce, w którym zaczęto budować zamek ${ }^{19}$, przekaz ten wymaga weryfikacji archeologicznej.

${ }^{12}$ Monomenta Poloniae Vaticana, t. 3, wyd. J. Ptaśnik, Kraków 1914, nr 312. Wcześniejsze wzmianki o parafii w Tarnowie (1326) odnoszą się do kościoła św. Marcina w Tarnowcu (Zawadzie), który stał się wówczas - za sprawą Spicymira - siedzibą dekanatu; S. Mateszew, F. Sikora, dz. cyt., s. 107; W. Dworzaczek, dz. cyt., s. 82.

13 Jeżeli nie jest ona wtórnie dobudowaną w późniejszym okresie (ok. 1400 r.?) - mogłaby stanowić dokument powiąania Spicymira z fundacjami królewskimi; T. Chrzanowski, M. Kornecki, Sztuka Ziemi Krakowskiej, Kraków 1982, s. 88.

${ }_{14}$ W. Dworzaczek, dz. cyt., s. 79. Najstarsze wzmianki o fortyfikacjach pochodza dopiero z 1448 r.; J. Widawski, Miejskie mury obronne w państwie polskim do poczqtku $X V$ wieku, Warszawa 1973. Ich rozbudowa i unowocześnienie miały miejsce w pierwszej połowie XVI w.; J.E. Dutkiewicz, Materiały źródłowe do budowy murów obronnych Tarnowa z lat 1513-1544, „Rocznik Historii Sztuki” 1, 1956, s. 237-301.

15 Teren ten miał wczesna tradycję osadnicza, nieopodal znajdowało się wczesnośredniowieczne grodzisko w Zawadzie; A. Jodłowski, Pradzieje i wczesne średniowiecze okolic Tarnowa, w: Tarnów. Dzieje..., t. 1, s. 63; A. Cetera, J. Okoński, Wiślański gród pod Tarnowem, „Z Otchłani Wieków” 50, 1984, z. 3-4, s. 166-169; ciż, Grodzisko wczesnośredniowieczne $w$ Zawadzie, gm. Tarnów, w: Badania archeologiczne w województwie tarnowskim w 1988 roku, Tarnów 1990, s. 23-27; ciż, Grodzisko wczesnośredniowieczne $w$ Zawadzie, gm. Tarnów, w: Badania archeologiczne $w$ województwie tarnowskim w 1989 roku, Tarnów 1991, s. 30-32; ciż, Grodzisko w Zawadzie - dziesięć lat później, „Rocznik Tarnowski” 1994, s. 287-310.

${ }_{16}$ W. Dworzaczek, dz. cyt., s. 79-80; E. Dworaczyński, J. Okoński, Zamek tarnowski, Tarnów 1986; E. Dworaczyński, Nowe ślady pierwszej fazy zamku na Górze Św. Marcina, w: Badania archeologiczne w województwie tarnowskim w 1985 roku, Tarnów 1986, s. 12-14; K. Moskal, In castro nostro tarnoviensi. Zamek tarnowski jako rezydencja, warownia i centrum administracyjno-gospodarcze dla dóbr tarnowskich, Tarnów 2001; M. Nowosad-Grylowa, Badania archeologiczne na zamku w Tarnowie, w: Polonia Minor medii aevii, red. Z. Woźniak, J. Gancarski, Kraków-Krosno 2003, s. 517-522.

17 Zob. przyp. 4.

${ }_{18}$ W. Dworzaczek, dz. cyt., s. 82.

19 Archiwum Prowincji Bernardynów w Krakowie, sygn. XIV-a-2, Daniel Zieliński, Archiwum Conventus Tarnoviensis Patrum Bernardinorum. 
Il. 3. Tarnów i wiejskie, lokacyjne układy ruralistyczne w jego otoczeniu; oprac. własne autora.

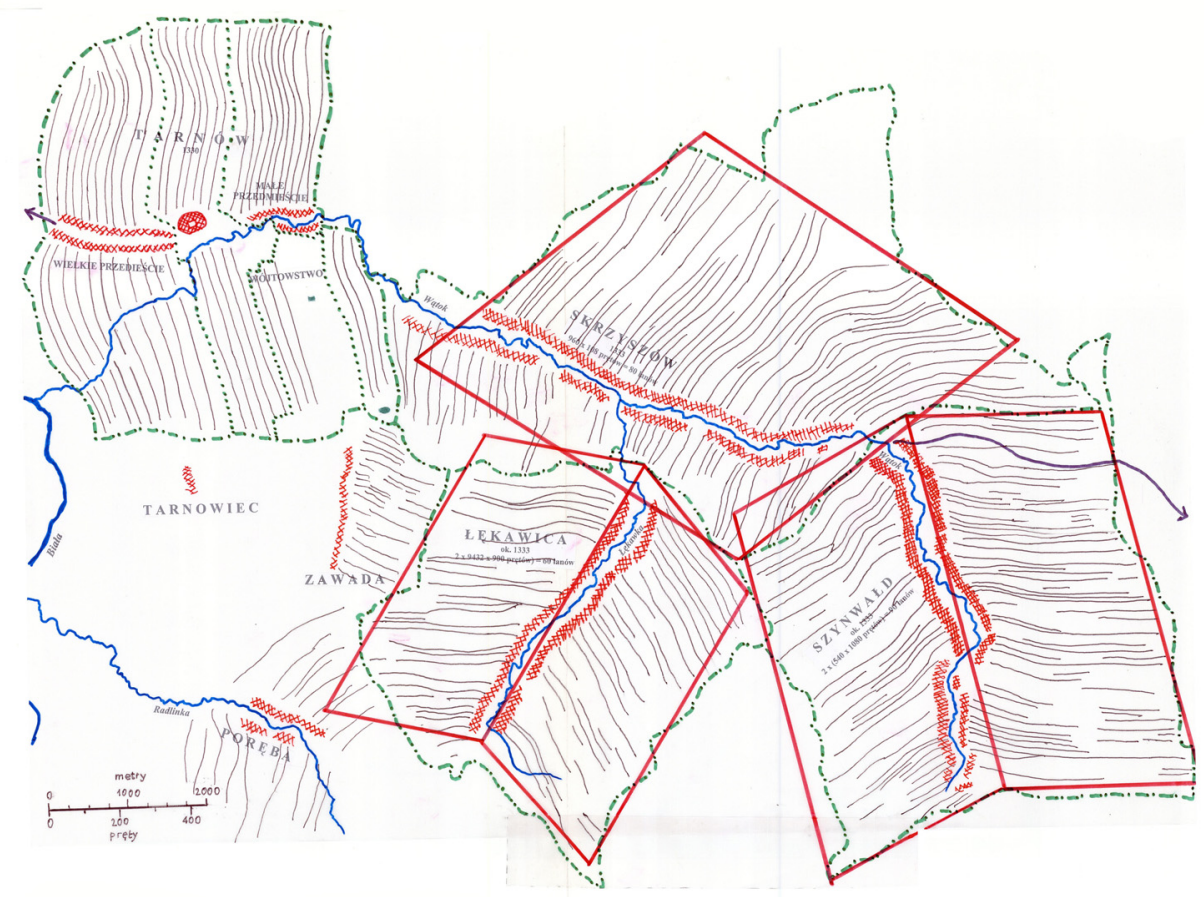

Analiza układów ruralistycznych w otoczeniu Tarnowa (il. 3) - Skrzyszowa, Łękawicy, Szynwałdu, Poręby (Radlnej) - świadczy o powiązaniu lokacji miasta z szersza akcją osadnicza. Tereny te zostały pozyskane przez Spicymira jednocześnie z Tarnowem Wielkim ${ }^{20}$. W $1331 \mathrm{r}$. Łokietek zatwierdził pozyskanie Skrzyszowa przez Spicymira, który dwa lata później wydał przywilej sołecki na osadzenie tej wsi na terenach leśnych. W 1342 r. kolejny zasadźca osadził Keyserwald ${ }^{21}$. Kompleks wsi obejmujacy Skrzyszów (80 łanów), Łękawicę (60), Szynwałd (90) i Porębę (Radlna) rozmierzono w oparciu o analogiczne zasady. Zapewne Spicymir przed 1350 r. erygował w Łękawicy, Porębie (Radlnej), Skrzyszowie i Szynwałdzie parafie ${ }^{22}$, poddanie ich prepozytom tarnowskim (1416) ${ }^{23}$ akcentowało jedność rodowego kompleksu dóbr i organizacji kościelnej.

\footnotetext{
${ }^{20}$ W. Dworzaczek, dz. cyt., s. 80.

21 Tamże.

${ }^{22}$ B. Kumor, Prepozytura tarnowska, „Archiwa, Biblioteki i Muzea Kościelne” 12, 1966, s. 236-238, 241-242, 245-249; W. Dworzaczek, dz. cyt., s. 82-83.

${ }^{23}$ W. Dworzaczek, dz. cyt., s. 199.
} 
Wypełnianie planu urbanistycznego Tarnowa murowana zabudową w późnym średniowieczu i nowożytności, a także wystrój tarnowskiej świątyni, awansowanej w $1400 \mathrm{r}$. do rangi kolegiaty, wybijają się ponad królewskie miasta porównywalnej wielkości.

W XV i na początku XVI w. do korpusu kolegiaty dobudowywano kaplice $^{24}$, prezbiterium od początku XVI do początku XVII w. zyskało funkcję rodowego mauzoleum. W drugim i trzecim dziesięcioleciu XVI w. działał tu budowlano-kamieniarski warsztat wawelski - wiazany z niewłoskimi współpracownikami Franciszka Florentczyka, prezentujący formy późnogotyckie, z próbą asymilacji italianizujących elementów renesansowych ${ }^{25}$ - w latach 1521 - około 1530 sam królewski architekt i rzeźbiarz Bartholomeo Berrecci ${ }^{26}$, później Jan Maria il Mosca zwany Padovanem ${ }^{27}$, Hieronim Canavesi (?) ${ }^{28}$ i Jan Pfister ${ }^{29}$.

Tarnów stawał się znaczącym ośrodkiem życia religijnego i kolejnych fundacji ${ }^{30}$. Rafał, syn Spicymira, zamierzał w 1359 r. ufundować klasz-

${ }^{24}$ Na przykład prawnuk Spicymira, Jan z Tarnowa, jako votum za grunwaldzka wiktorię (w której uczestniczył), ufundował w 1415 r. przy kolegiacie kanonię Rozesłania Apostołów (W. Dworzaczek, dz. cyt., s. 182, 187, 199), z czym wiązała się budowa późnogotyckiej kaplicy.

25 B. Krasnowolski, Krakowskie warsztaty budowlane $i$ kamieniarskie na przetomie średniowiecza i nowożytności, „Rocznik Krakowski” 72, 2006, s. 101. Dziełem tego warsztatu byłby w prezbiterium nagrobek zmarłej w 1517 r. Barbary z Rożnowa Tarnowskiej oraz portale kolegiaty z około 1514 r.: południowy (z herbami Leliwa i Szternberg, odnoszącymi się do zmarłego w 1500 r. Jana Amora Tarnowskiego) i skromniejszy zachodni (E. Trajdos, Treści ideowe nagrobka Barbary z Rożnowa katedrze tarnowskiej, „Archiwa, Biblioteki i Muzea Kościelne” 9, 1964, s. 47-64; taż, Portal południowy katedry w Tarnowie, „Biuletyn Historii Sztuki” 22, 1960, $\mathrm{nr} 2$, s. 179-184), w zespole kolegiackim zaś jeden $\mathrm{z}$ domów kapitulnych (tzw. Mikołajowski) z $1524 \mathrm{r}$.

${ }^{26}$ Autor wybitnych dzieł rzeźby renesansowej: nagrobków Barbary Tarnowskiej (zmarłej w 1521) oraz Jana Amora (młodszego) i Jana Tarnowskich (ok. 1530), ojca i przyrodniego brata hetmana Jana Tarnowskiego, fundatora dzieła; A. Fischinger, $Z e$ studiów nad twórczościa Bartłomieja Berrecciego i jego warsztatem: nagrobki Szydtowieckich $i$ Tarnowskich, „Folia Historiae Atrium” 10, 1974, s. 117-135.

${ }^{27}$ Autor monumentalnego nagrobka ostatnich Tarnowskich: hetmana Jana (zm. 1561) i Jana Krzysztofa (1567); A.M. Schulz, Giammaria Mosca called Padovano. A Renaissance Sculptor in Italy and Poland, University Park (PA) 1998.

${ }^{28}$ Zapewne był autorem nagrobka Zofii z Tarnowskich Ostrogskiej, zmarłej w 1570 r. córki hetmana; W. Szczebak, Tarnowska bazylika katedralna. Dzieje i sztuka, Tarnów 2007, s. 90, 92.

${ }^{29}$ Jego dziełem - i może związanego m.in. z Gdańskiem Flamanda Wilhelma van den Blocke - jest ogromny nagrobek Janusza i Zofii Ostrogskich, ukończony w 1620 r.; P. Krakowski, Pomnik nagrobny ks. Ostrogskich (w Tarnowie), „Studia Renesansowe" 2, 1957, s. 263-299.

${ }^{30}$ A. Leo, Tarnowskie kościoły, Tarnów 2000. 
Il. 4. Bobowa, analiza lokacyjnego planu urbanistycznego według autora i późniejszego systemu obronnego według Jerzego Tura: A - kurtyny bastionu, B - relikt bastei lub bastionu, C - relikt bastei, D - relikty wału, E - relikty fosy, $\mathrm{F}$ - relikt bastei; oprac. własne autora.

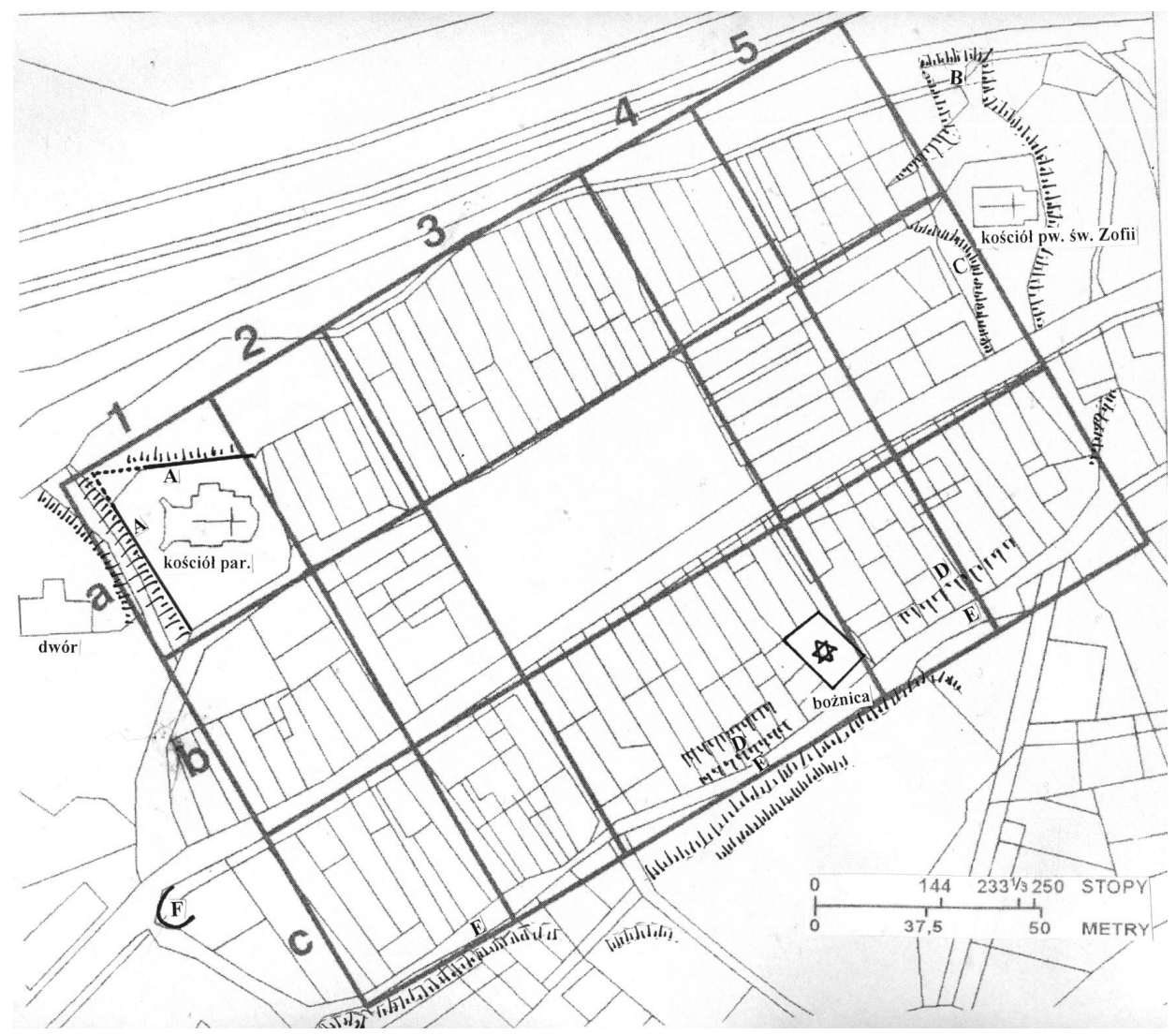

tor Franciszkanów ${ }^{31}$. Do realizacji doszło po stu latach, gdy Jan Amor Tarnowski ufundował zespół bernardyński ${ }^{32}$. Kolejne kościoły w obrębie przedmieść wznoszono od połowy XV do XVII w.

Schyłek średniowiecza i początek nowożytności to rozwój architektury świeckiej - późnogotyckiej, renesansowej, manierystycznej -

${ }^{31}$ W. Dworzaczek, dz. cyt., s. 96-97.

32 B.P. Siwiec, Bernardyni tarnowscy latach 1459-1939. Zarys dziejów klasztoru Zakonu Braci Mniejszych w Tarnowie, Tarnów 1999. O bogactwie pierwotnego wyposażenia świątyni (gruntownie przebudowanej w latach 1823-1825 na cele świeckie) świadczyły okazałe, późnogotyckie stalle z 1504 r.; B. Krasnowolski, Gotyckie stalle bernardyńskie $z$ Tarnowa, „Rocznik Tarnowski” 1991/1992, s. 25-30 (relikt zachowany w Muzeum Bernardynów w Leżajsku). 
wypełniającej lokacyjny układ urbanistyczny. Późnogotycki ratusz ${ }^{33}$ (przełom XV i XVI w.) gruntownie przebudowano jako renesansowy (1558-1561) z inicjatywy Jana Tarnowskiego, może z udziałem Padovana; w blendach attyki umieszczono poczet panów Tarnowa. $\mathrm{W}$ tym samym czasie kształtowano mieszczańskie kamienice przyrynkowe, otrzymujace $\mathrm{w}$ dobie renesansu podcienia i attyki.

W nowożytnych przekształceniach Tarnowa istotną rolę odgrywali Żydzi ${ }^{34}$. Pojawili się tu - na Małym Przedmieściu - może już w XIV w. Od drugiej połowy (końca?) XVI w. osiadali w mieście, tworzac skupisko znajdujace odzwierciedlenie w nazwie ul. Żydowskiej i zabudowie; charakterystyczny podział działek siedliskowych na niewielkie, wąskofrontowe posesje widoczny jest na archiwalnych planach miasta ${ }^{35}$. W tymże okresie (początek lat 80. XVI w.?) pod murem obronnym powstała drewniana bożnica (około 1630 r. zastapiona murowana, później przekształcana), a w kompleks ról Małego Przedmieścia wpisany został cmentarz.

Podobne relacje między lokacyjnym układem urbanistycznym a styczną do niego siedzibą właściciela (wzmacniająca obwód obronny), zachodziły w Bobowej, Gorlicach, Szymbarku i Chrzanowie; gdybyśmy potrafili udowodnić tezę bernardyńskiego kronikarza - do grupy tej można by zaliczyć Tarnów.

Bobową, miasto w dobrach Gryfitów ${ }^{36}$, lokowano przed 1346 r. Układ urbanistyczny ${ }^{37}$ (il. 4), wykazujący zbieżność ze starszym Bieczem, rozciagnięty jest pomiędzy stromą szkarpą rzeki Białej i łagodniejszym obniżeniem. Obok, oddzielona głębokim parowem (suchą fosa), znalazła się (od lokacji?) siedziba właściciela, chroniona tą samą skarpą rzeczna.

Fundacjami rycerskich patronów były murowane, gotyckie kościoły: parafialny Wszystkich Świętych z przełomu XIV i XV w. (z rycerskimi

${ }^{33}$ B. Krasnowolski, Ekspozycja muzealna jako interpretacja historycznych $i$ artystycznych wartości ratusza w Tarnowie, „Arkusze Muzealne” (Nowy Sącz) 1975.

${ }_{34}$ M. Trusz, Synagoga Stara $w$ Tarnowie, „Rocznik Tarnowski” 1991/1992, s. 31-39; M. i K. Piechotkowie, Oppidum Judaeorum. Żydzi w przestrzeni miejskiej dawnej Rzeczypospolitej, Warszawa 2004; ciż, Bramy nieba. Bożnice murowane na ziemiach dawnej Rzeczypospolitej, Warszawa 1999.

${ }_{35}$ Plany reprodukowane: J.E. Dutkiewicz, Tarnów, Warszawa 1954.

${ }^{36}$ Interpretacja źródeł pisanych: Z. Tabaka, Zarys dziejów miasteczka Bobowej do 1914 r., w: Nad rzeka Ropa, cz. 3: Szkice historyczne, red. F. Kiryk, Kraków 1968; F. Kiryk, Rozwój urbanizacji Małopolski XIII-XVw. Województwo krakowskie (powiaty południowe), Kraków 1985, s. 46-49; Z. Leszczyńska-Skrętowa, Bobowa, w: Stownik historyczno-geograficzny województwa krakowskiego w średniowieczu, cz. 1, Wrocław 1980 (dalej: SHG), s. 140-146.

${ }^{37}$ Analiza modularna wskazuje, że zastosowano tu „krakowski” system miar: stopę wartości $0,293 \mathrm{~m}$, sznur $=150$ stóp $(43,95 \mathrm{~m})$ i pręt $=15$ stóp $(4,395 \mathrm{~m})$; B. Krasnowolski, Lokacyjne uktady..., cz. 2, s. 23-27. 
herbami na zwornikach sklepienia prezbiterium) i przedmiejski św. Zofii (po połowie XV w.), zbudowany być może przez warsztat budowlany pracujący dla Jakuba z Dębna ${ }^{38}$. Wyrazem troski o miasteczko ze strony właścicieli był system obronny ${ }^{39}$, kształtowany od XIV do XVII w., obejmujący wał prowadzony krawędzia szkarpy miejskiej i fosę, wykorzystujące walory obronne obu świątyń i skarpy rzecznej, wzmacniany w XVI w. ziemnymi bastejami, a w połowie XVII stulecia m.in. bastionem ujmującym cmentarz kościoła parafialnego.

Egzystencję drewnianego miasteczka zniszczonego pożarem (1703) podtrzymywali Żydzi, osiedleni tu w 1732 r. ${ }^{40}$ Wkrótce po przybyciu wznieśli przy linii obronnej murowaną bożnicę ${ }^{41}$ i założyli cmentarz w obrębie ról.

Lokacji Gorlic ${ }^{42}$ dokonano po połowie XIV w. staraniem nobilitowanego mieszczanina krakowskiego Dziersława Karwacjana, który zyskał terytorium nad środkowym biegiem Ropy dla prowadzenia kolonizacji. Miasto (il. 5) ${ }^{43}$ zajęło obronne położenie nad stromą skarpą Ropy, podobnie jak styczna doń murowana siedziba właścicieli4 ${ }^{4}$, również wykorzystujacca walory rzecznej skarpy.

${ }^{38}$ Tenże, Między Wschodem a Zachodem. Studia nad historia i sztuka pogranicza polsko-temkowskiego, Torú 2010, s. 106-108.

${ }^{39}$ Archiwum delegatury WKZ w Nowym Saczu, Jerzy Tur, Bobowa, fortyfikacje miasta, karta ewidencyjna, 1968.

${ }^{40}$ M. Wójcikiewicz, Zarys rozwoju przestrzennego miasta Bobowej, „Teka Komisji Urbanistyki i Architektury" 16, 1982, s. 119-124.

${ }^{41}$ M. i K. Piechotkowie, Bramy nieba..., s. 359. Była ona ukończona przed kolejnym pożarem Bobowej (1756), gdy wzmiankowano ją w Liber documentorum kościoła św. Zofii; S. Tomkowicz, Powiat grybowski, „Teka Grona Konserwatorów Galicji Zachodniej” 1900, nr 1, s. 106.

${ }^{42}$ Interpretacje źródeł pisanych: F. Kiryk, $Z$ dziejów miast $w$ zachodniej części ziemi bieckiej do 1520 r., w: Nad rzekq Ropq..., cz. 3, s. 133; J. Laberschek, Gorlice, w: SHG, cz. 1, s. 792-799.

${ }^{43}$ Kompozycję układu urbanistycznego można określić jako dziewięciopolowa, złożoną z kwadratów o boku 2 sznurów (sznur $=150$ stóp, stopa $=0,30 \mathrm{~m}$ ), z których środkowy jest rynkiem, jeden zaś z narożnych (wschodni) przeznaczono dla kościoła parafialnego; B. Krasnowolski, Lokacyjne układy..., cz. 2, s. 68-73.

${ }_{44}$ J. Bogdanowski, Obronna wieża mieszkalna dworu Karwacjanów w Gorlicach, $\mathrm{w}$ : Architektura rezydencjonalna $i$ obronna województwa rzeszowskiego $w$ świetle badań ratowniczych prowadzonych w 25-leciu PRL. Materiaty z sesji naukowej, Łańcut 9-10 maja 1970, Łańcut 1972, s. 77-83 - najstarszą fazę budowlaną zespołu datuje dopiero na wiek XV, wzniesienie wieży zaś widzi w fazie kolejnej (XV - pierwsza połowa XVI w.); zob. też S. Kołodziejski, Średniowieczne rezydencje obronne możnowładztwa na terenie województwa krakowskiego, Kraków 1994, s. 131-132. Zdaniem niżej podpisanego nie można wykluczyć wcześniejszego datowania początków siedziby, bliskiego lokacji miasta. 
Il. 5. Gorlice, analiza lokacyjnego planu urbanistycznego; oprac. własne autora.

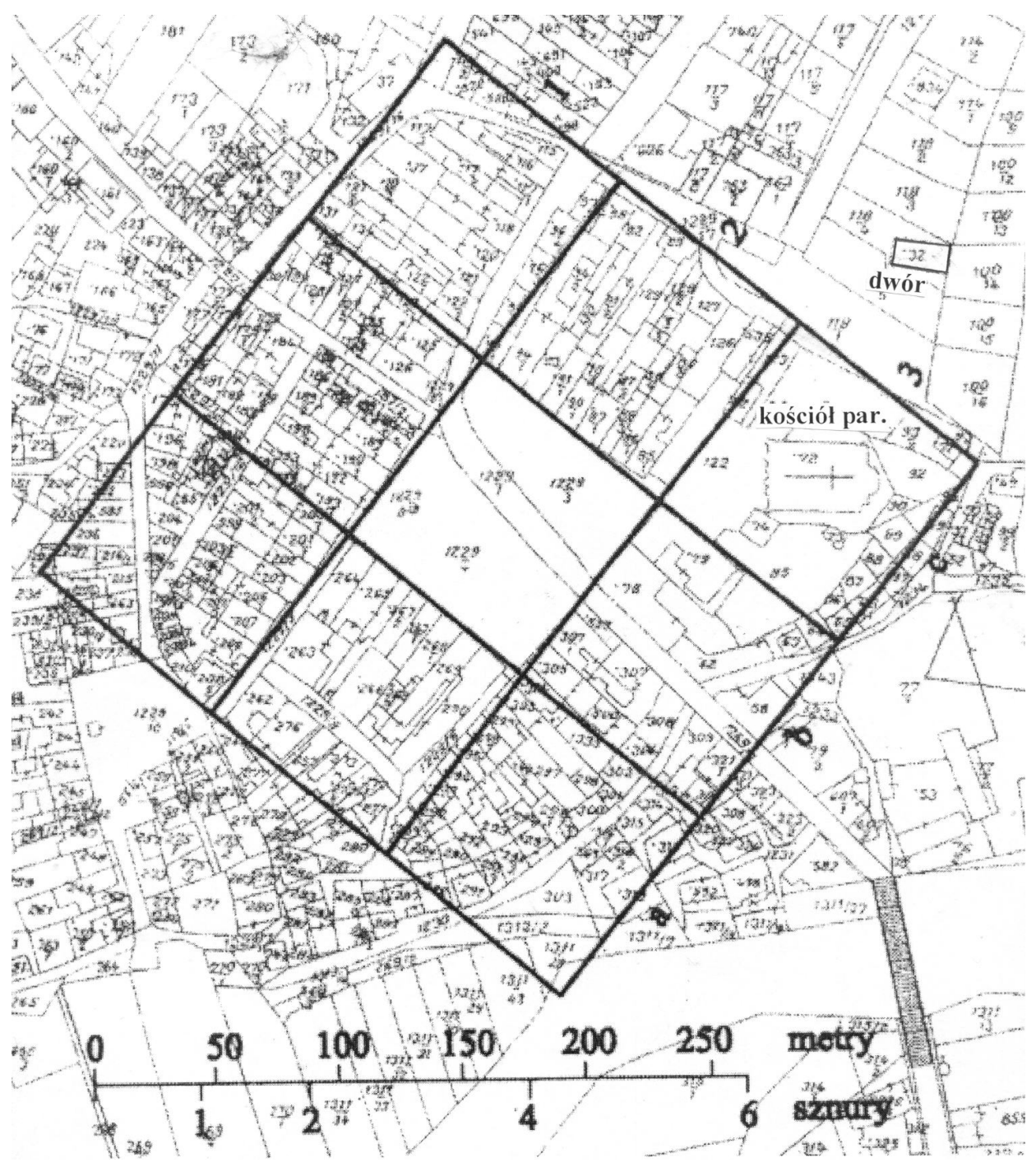

Miasto Szymbark ${ }^{45}$ lokowane było zapewne staraniem Jana Gładysza, po uzyskaniu przezeń od króla terenów położonych nad Ropa (1368-1369). Proces osadniczy rozpoczą się jednak wraz z erekcja parafii (1359), wójta wzmiankowano w 1388 r. Układ urbanistyczny (związany z lokalną nazwa „Miastko”) został niemal całkowicie zatarty

${ }^{45}$ Interpretacja źródeł pisanych: F. Kiryk, Rozwój urbanizacji..., s. 80-82; tenże, $Z$ dziejów miast..., s. 142; niepublikowane materiały do hasła Szymbark w redakcji SHG. 
po utracie statusu miejskiego w XVI w. Podobnie jak w Bobowej i Gorlicach wykorzystano obronne położenie nad skarpa rzeczna. Możliwe, że od początku miasto sprzężono z siedzibą właściciela, której domyślać się należy w miejscu renesansowego dworu ${ }^{46}$. Miasto i rezydencja stanowiłyby tu centrum rycerskich dóbr, w obrębie których osadzano wsie.

Data lokacji Chrzanowa ${ }^{47}$ Ligęzów herbu Półkozic (przed 1325-1327 ?) nie jest znana. Sytuacja centrum osadniczego ${ }^{48}$ na zboczu wzgórza może być wyjaśniona tylko wcześniejszym zajęciem kulminacji przez siedzibę kasztelana (XIII w.) ${ }^{49}$, a później przez lokacyjne wójtostwo, którego wykup (1408) ${ }^{50}$ zapoczątkował rozwój siedziby właściciela (il. 6). Dwór wspominają źródła od XVII w., od końca tego stulecia określano go jako „zamek” ${ }^{51}$. Analiza projektu rozbudowy z $1857 \mathrm{r}^{52}$ wskazuje na fazę późnośredniowieczną (pierwsza połowa XVI w.?) i nowożytna z przełomu XVI i XVII w. Peryferyjny charakter dóbr (właściciele rezydowali w Bobrku) sprawiał, że zabudowa miasteczka była drewniana, jednak co najmniej od pierwszej połowy XVII w. bogatsi mieszczanie budowali przy rynku „kamienice” ${ }^{53}$.

${ }^{46}$ Budowla o późnogotyckiej tradycji powstała w okresie 1530-1550, przebudowy z lat 1585-1590 i początku XVII w. - a więc po zaniku miasta - ukształtowały renesansowa bryłę i wystrój wnętrz; K. Sinko-Popielowa, S. Świszczowski, Dwór obronny w Szymbarku, „Biuletyn Historii Sztuki i Kultury” 6, 1938; M. Dayczak-Domanasiewicz, Uwagi o architekturze renesansowych dworów $w$ Jeżowie $i$ Szymbarku $w$ powiecie gorlickim, w: Architektura rezydencjonalna i obronna województwa rzeszowskiego, Łańcut 1972.

${ }^{47}$ Interpretacja źródeł pisanych: Z. Leszczyńska-Skrętowa, Chrzanów, w: SHG, cz. 1, s. 379-383; F. Kiryk, Chrzanów na przełomie średniowiecza i czasów nowożytnych, „Studia Historyczne” 39, 1996; Z. Wojas, Chrzanów średniowieczny i nowożytny do połowy XVII w., w: Chrzanów. Studia z dziejów miasta i regionu do roku 1939, t. 1, Chrzanów 1998, s. 61-110.

${ }^{48}$ Lokacyjny układ urbanistyczny rozmierzony został - jak wynika z analizy modularnej $-\mathrm{w}$ oparciu o stopy $0,30 \mathrm{~m}$ i ich wielokrotności: małe sznury $=125$ stóp $(37,5 \mathrm{~m})$ i pręty $=12 \frac{1}{2}$ stopy $(3,75 \mathrm{~m})$; B. Krasnowolski, Lokacyjne uktady ..., cz. 2, s. $40-45$, il. 44 .

${ }^{49}$ Z. Motyka, Kasztelania chrzanowska, w: Chrzanów. Studia z dziejów..., t. 1, s. $43-57$.

${ }^{50}$ Z. Leszczyńska-Skrętowa, Chrzanów..., s. 382.

51 J. Stoksik, Wtaściciele Chrzanowa od poczatku XVII do 1. pot. XIX w. i ich stosunek do miasta, w: Chrzanów. Studia z dziejów miasta..., t. 1, s. 117; Rejestr poborowy województwa krakowskiego z roku 1680 wraz $z$ aneksem miast $z$ roku 1655, red. S. Ingot, Wrocław 1959, s. 328.

${ }^{52}$ ANK, Zbiór kartograficzny - różne miejscowości: Chrzanów, Plan sytuacyjny budynków dworskich przeznaczonych do umieszczenia Sądu Obwodowego w mieście Chrzanowie.

${ }^{53}$ B. Krasnowolski, Zabytki i wartości kulturowe, w: Chrzanów. Studia z dziejów miasta i regionu do roku 1939, t. 2, cz. 1, Chrzanów 1999, s. 347-349. Już w 1559 r. Chrzanów miał cegielnię miejska; Z. Wojas, dz. cyt., s. 87. 
Il. 6. Chrzanów, relacja pomiędzy lokacyjnym układem urbanistycznym a siedzibą właściciela (po stronie zachodniej) na planie katastralnym, 1848 r.; za: B. Krasnowolski, Lokacyjne uktady urbanistyczne na obszarze Ziemi Krakowskiej $w$ XIII $i$ XIV wieku, cz. 2, Kraków 2004, s. 42.

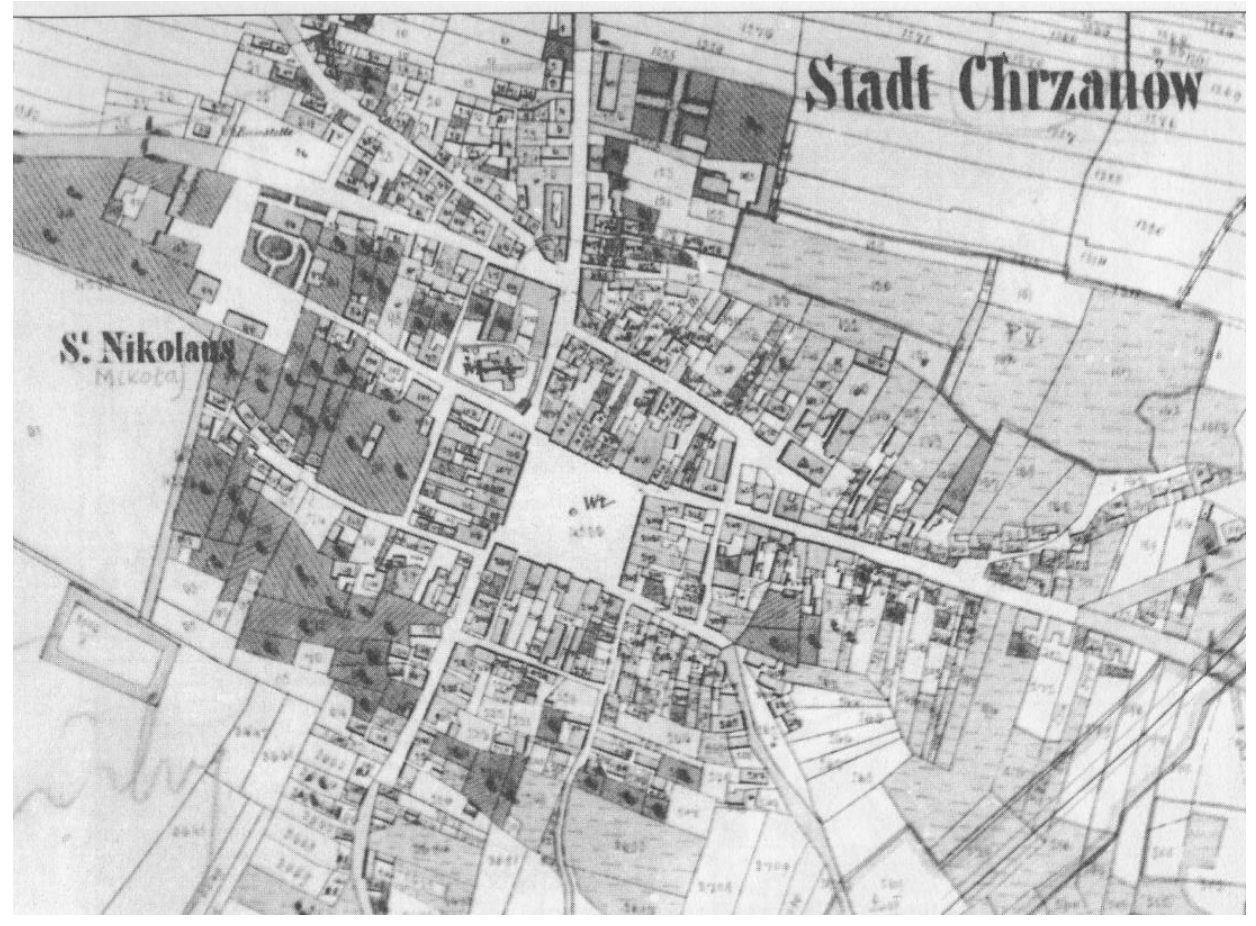

Zapewne od końca XVI stulecia na przedmieściu przy drodze do Krakowa mieszkali Żydzi. Gmina wykształciła się w XVIII w. ${ }^{54}$, w drugiej połowie stulecia istniał bet ha-midrasz i synagoga ${ }^{55}$, wzmiankowano również rabina ${ }^{56}$.

${ }^{54}$ Por. J. Stoksik, Chrzanów i jego mieszkańcy od poczqtku XVII do poczqtku XIX wieku, w: Chrzanów, studia z dziejów..., t. 1, s. 177-178; F. Zacny, Żydzi w Chrzanowie $w$ XVII $i$ XVIII wieku, w: tamże, s. 283-306.

${ }^{55}$ Dokument hipoteczny z 1828 r. wspomina „szkołę Bet Hamedres”, obciążona w 1759 r. zapisem „na rzecz funduszu plebanii w Chrzanowie”; ANK, Akta hipoteczne Chrzanowa, sygn. WMK 361a. W 1785 r. zezwolenie na budowę synagogi - zwanej później, w odróżnieniu od owego bet ha-midraszu „Wielką - wydał w arcybiskup Michał Jerzy Poniatowski (por. ANK, sygn. APA 31, Inwentarz kościoła parafialnego w Chrzanowie, po 1791: „Bożnica znajduje się w Chrzanowie, za konsensem [...] Prymasa i Administratora Diecezji Krakowskiej pod rokiem 1785"). W 1787 r. zakupiono od mieszczan parcelę na budowę oraz zawarto umowę na dostawę materiałów budowlanych z właścicielem dóbr chrzanowskich, Józefem Salezym Ossolińskim, dług ten gmina żydowska spłacała, świadcząc na rzecz chrzanowskiego szpitala ubogich; ANK, 
Kolejną grupę stanowią miasta z siedzibami właścicieli kształtowanymi bez związku z lokacja, wcześniejszymi lub późniejszymi od lokacyjnego układu urbanistycznego.

Przykładem zmian relacji między miastem lokacyjnym a siedziba właściciela - odmienną w średniowieczu, odmienną w dobie nowożytnej - jest Książ Wielki. Mimo całkowitego niemal zatarcia układu urbanistycznego (przetrwały sytuacje kościołów: parafialnego i augustiańskiego) oraz braku szczegółowych źródeł planistycznych, relacje te sa do dziś czytelne. Lokacja miasta ${ }^{57} \mathrm{w}$ dobrach Leliwitów nastapiła najpóźniej w 1372 r., za jej konsekwencję uznać można dokonaną fundację zespołu augustiańskiego przez Jana z Melsztyna.

Lokację wyprzedziło ukształtowanie warownej siedziby rycerskiej (przełom XIII i XIV w., może Adama z Książa herbu Janina, wzmiankowanego w latach $1314-1336)^{58}$ na terenie zalewowym strumienia, którego wody zapełniały fosę, kolejną zapora obronnego kręgu był wał. Założenie funkcjonowało do początku XVI w.

Lata 1585-1595 przyniosły charakterystyczne dla nowożytności, kompozycyjne powiązanie z miastem nowej siedziby właściciela. $\mathrm{Na}$ kulminacji wzniesienia ukształtowany został staraniem biskupa humanisty Piotra Myszkowskiego, przez architekta Santi Gucciego, zespół pałacu „Na Mirowie”59 (nazwę przejęto z rodowej siedziby Myszkowskich, zamku Mirów). Kompozycję, z pałacem jako centralnym elementem, oparto na skierowanej ku miastu osi.

Podobne zmiany w relacjach miasto lokacyjne - siedziby właścicieli spotykamy w Pilicy. Lokacji miasta ${ }^{60}$ jako „Nowej Pilicy” dokonano staraniem Toporczyków (Pileckich) na surowym korzeniu, na terenach wsi Pilica (,Stara”), w okresie 1373-1394 (il. 7) ${ }^{61}$. Odsunięcie kościoła

Akta hipoteczne Chrzanowa, sygn. WMK 361a. Bożnicę rejestruje m.in. plan miasta z 1838 r.; ANK, WMK-Okr.277. Została zburzona przez władze PRL po 1968 r.

${ }_{56}$ M. Bałaban, Studia historyczne, Warszawa 1927, s. 157.

${ }^{57}$ Interpretacje źródeł pisanych: J. Kurtyka, Ksiaż Wielki, w: SHG, cz. 3, z. 2, Kraków 1997, s. 291-313.

${ }^{58}$ G. Leńczyk, Obronny dwór średniowieczny $w$ Ksiażu Wielkim $w$ pow. miechowskim, „Z Otchłani Wieków” 17, 1948, z. 5-6, s. 81-82; S. Kołodziejski, Średniowieczne rezydencje obronne..., s. 153-154.

59 A. Fischinger, Santi Gucci, architekt i rzeźbiarz królewski XVI wieku, Kraków 1969, s. $18-24$.

${ }^{60}$ Interpretacja źródeł pisanych: F. Kiryk, Pozostałe miasta regionu olkuskiego, w: Dzieje Olkusza i regionu olkuskiego, red. F. Kiryk, R. Kołodziejczyk, Kraków 1978, s. $346-347$.

${ }^{61}$ System miar to stopy $=0,30 \mathrm{~m}$, pręty $=4,50 \mathrm{~m}$, sznury $=45 \mathrm{~m} ; \mathrm{B}$. Krasnowolski, Lokacyjne uktady..., cz. 2, s. 180-183. 
Il. 7. Pilica, analiza lokacyjnego planu urbanistycznego; za: B. Krasnowolski, Lokacyjne uktady urbanistyczne na obszarze Ziemi Krakowskiej $w$ XIII i XIV wieku, cz. 2, Kraków 2004, s. 183.

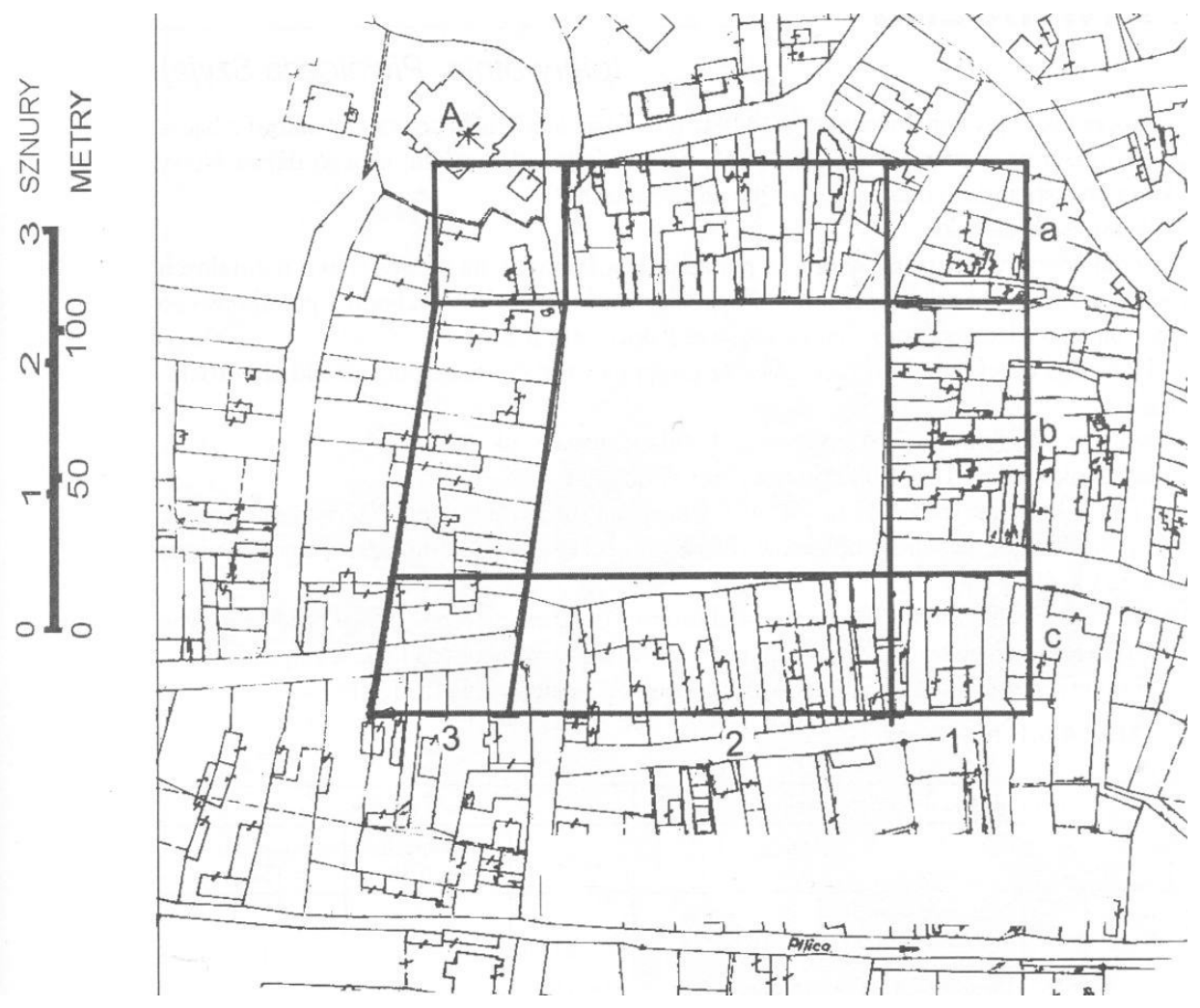

parafialnego od narożnika rynku wynikać może z późniejszej genezy, po lokacji siedziba parafii mógł być kościół w „Starej” Pilicy.

Średniowieczny zamek na skalistym wzgórzu Smoleń w Starej Pilicy ${ }^{62}$ powstał wcześniej, być może staraniem Jana z Pilicy, wzmiankowanego w latach 40. XIV w. Po połowie XVI w. zamek opuszczono, a dobra przeszły w ręce Padniewskich, którzy w 1610 r. przenieśli siedzibę w pobliże miasta. Okazałe formy typu palazzo in fortezza nadał tej rezydencji Jerzy Zbaraski około $1620 \mathrm{r} .{ }^{63} \mathrm{~W}$ XVIII w. symetrię założenia zaakcentowała oś wiążąca rezydencję z kompleksami rolnymi.

${ }^{62}$ S. Kołodziejski, Średniowieczne rezydencje obronne..., s. 167.

${ }^{63}$ J. Janczykowski, Zamek Jerzego Zbaraskiego w Pilicy - rezydencja „militaris”, w: Dzieto sztuki a konserwacja. Materiały 52 Ogólnopolskiej Sesji Naukowej SHS, Kraków 20-22 XI 2003, Kraków 2004, s. 173-193; tenże, Zamek w Pilicy na tle architektury rezydencjonalno-obronnej $w 1$ połowie XVII w. $w$ Polsce, Kraków 2015, mps pracy doktorskiej, Politechnika Krakowska. 
Brak związku kompozycyjnego między miastem lokacyjnym a nowożytną rezydencją właściciela obserwujemy też w Dukli, gdzie kolejność lokacyjnych procesów osadniczych od drugiej połowy XIV do przełomu XIV i XV w., od prób osadzania wsi do wydzielenia z niej w kolejnym etapie miasta ${ }^{64}$ (il. 8) była podobna jak w Tarnowie. Lokacja wsi rozpoczęła się w okresie 1355-1357 staraniem Jana Suchywilka herbu Grzymała, późniejszego kanclerza wielkiego koronnego i arcybiskupa gnieźnieńskiego. Informację z dokumentu z 1373 r. o rozpoczętym przed 16-18 laty zakładaniu wsi na 60 łanach frankońskich po obu stronach potoku odnajdujemy w terenie, z nawsiem w dolinie Dukielki i rolami, które można wpisać w prostokąt o takiej właśnie powierzchni. Dwa z tych łanów oraz łąkę zwaną Lipowica przeznaczono dla zasadźców, którzy stawali się dziedzicznymi sołtysami, jeden stanowić miał uposażenie kościoła parafialnego pw. św. Marcina.

Osadzenie lokacyjnej wsi Dukla było etapem wstępnym, jakby próba przed lokacja miasta, przedsięwzięta staraniem jednego z kolejnych właścicieli w 1380 r., a do 1402 r. jeszcze nieukończona ${ }^{65}$. W wyniku lokacji miasta jego areał rolny wydzielono ze wschodniej części areału wsi, zwanej odtąd Stara Duklą lub przedmieściem. Centrum miasta (il. 9) ${ }^{66}$ zlokalizowano na niewysokim wzniesieniu (teren wcześniejszego sołectwa?), nad ujściem Dukielki do Jasiołki, przy czym koryta potoków traktowano zapewne jako element obronny. Lokacyjna Dukla, podobnie jak zdecydowana większość polskich miast, nie miała trwałych, murowanych fortyfikacji. W nieokreślonym bliżej czasie otrzymała umocnienia drewniano-ziemne w postaci wałów, ich obecność zdaje się potwierdzać nazwa ul. Podwalnej. Zapewne w pierwszej połowie XVII stulecia dokonywano modernizacji systemu obronnego, wprowadzając ziemne basteje, z niezachowanymi dziś elementami murowanymi: wspominanymi w źródłach bramami Krakowską i Węgierską ${ }^{67}$. Uwagę zwraca

${ }^{64}$ Interpretacja źródeł pisanych dla średniowiecza: F. Kiryk, Rozwój urbanizacji..., s. 64-68; F. Sikora, Dukla, w: SHG, cz. 1, z. 4, Kraków 1986, s. 625-629; tenże, Dukla Stara albo Przedmieście Dukielskie, w: tamże, s. 639-631.

${ }^{65}$ A. Kamiński, Nieznane karty z dziejów Dukli, w: Prace z dziejów Polski feudalnej ofiarowane Romanowi Grodeckiemu w 70 rocznice urodzin, Warszawa 1960, s. 401-430; F. Sikora, Dukla..., s. 627-628.

66 Analiza modularna wskazuje, że zastosowano tu nieco inne wartości miar, niż wcześniej przy rozmierzeniu uposażenia rolnego (pręt $=4,50 \mathrm{~m}$ ): podstawą były: sznur $=47,10 \mathrm{~m}$, pręt $=4,71 \mathrm{~m}$, stopa $=0,314 \mathrm{~m} ;$ B. Krasnowolski, Lokacyjne uktady..., cz. 1 , s. $139-140$.

${ }^{67}$ Katalog zabytków sztuki w Polsce, seria nowa, t. 1: Województwo krośnieńskie, z. 1: Krosno, Dukla i okolice, oprac. E. Śnieżyńska-Stolotowa, F. Stolot, Warszawa 1977, s. 13. 
Il. 8. Dukla, lokacja wsi i wydzielenie miasta: rozmierzenie ról i centra osadnicze: 1-1 - nawsie Starej Dukli w obrębie późniejszego Przedmieścia Górnego, 2-2 - nawsie Starej Dukli w obrębie późniejszego Przedmieścia Dolnego, 3 - lokacyjne centrum miasta Dukli, 4 - miejsce siedziby wójtowskiej (?), x - sytuacja wiejskiego kościoła parafialnego św. Marcina, a-a - lasy na terenach nie podzielonych na łany, b - sytuacja łąki Lipowica; za: B. Krasnowolski, Lokacyjne układy urbanistyczne na obszarze Ziemi Krakowskiej w XIII i XIV wieku, cz. 2, Kraków 2004, s. 67.

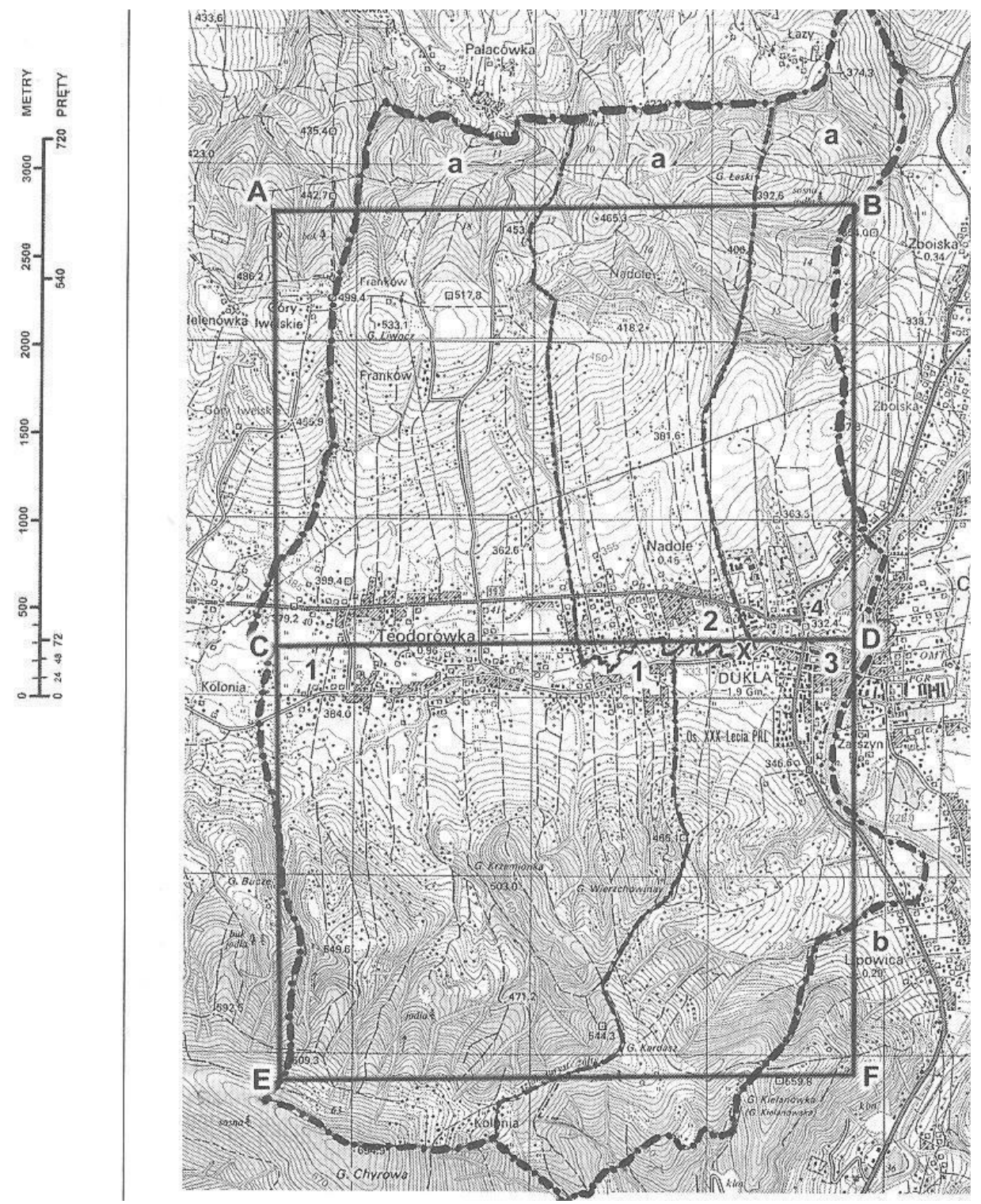


Il. 9. Dukla, analiza lokacyjnego planu urbanistycznego; za: B. Krasnowolski, Lokacyjne uktady urbanistyczne na obszarze Ziemi Krakowskiej $w$ XIII i XIV wieku, cz. 2, Kraków 2004, s. 66.

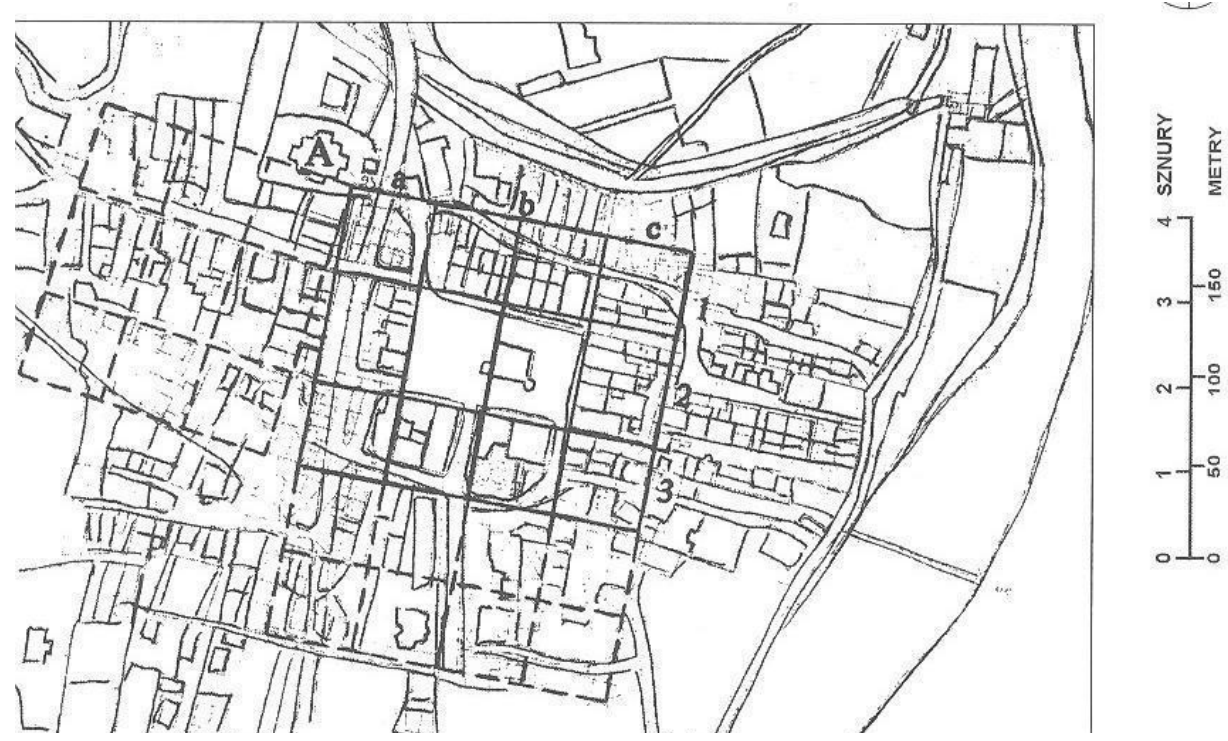

długotrwały brak miejskiego kościoła parafialnego, rolę tę nadal pełnił kościół wiejski. Parafialny kościół pw. św. Marii Magdaleny po raz pierwszy wspomniano w $1503 \mathrm{r} .{ }^{68}$ Ograniczony rozwój murowanej zabudowy nastapił na przełomie wieków XVI i XVII oraz w pierwszej połowie XVII stulecia, na okres ten można datować najstarsze zachowane elementy przyrynkowych kamienic, w $1611 \mathrm{r}$. wspomniano po raz pierwszy ratusz. Postępy zabudowy murowanej nastapiły po pożarze z $1758 \mathrm{r} .{ }^{69}$

Nie wiemy, czy w programie średniowiecznej Dukli znajdowała się siedziba właściciela. Murowany dwór z połowy XVI w. wiązać można z Janem Jordanem z Zakliczyna ${ }^{70}$. W 1635 r. Duklę nabył Franciszek

${ }^{68}$ F. Sikora, Dukla..., s. 626, 628. O translacji parafii wspominaja wizytacje biskupie z przełomu wieków XVI i XVII. Zapewne do doby fundacji odnieść należy najstarszy element dzisiejszego kościoła: trójboczne zamknięcie prostokątnego prezbiterium. Korpus jeszcze na przełomie wieków XVI i XVII był drewniany; Archiwum Kurii Metropolitalnej w Krakowie, sygn. A.V. Cap. 2, k. 141-142; A.V. Cap. 21, s. 84; A.V. Cap. 26, s. 362.

${ }^{69}$ Katalog zabytków..., s. 29-31.

70 J. Marszałek, Katalog grodzisk $i$ zamczysk $w$ Karpatach, Warszawa 1993, s. 81-83; por. też F. Sikora, Dukla..., s. 627. O ambicjach właściciela jako mecenasa może świadczyć piękny ornat $\mathrm{z}$ renesansowych, włoskich altembasów, ufundowany - zapewne przezeń, jak świadczy haft z herbem Trąby i datą 1540 - dla miejscowego kościoła parafialnego, znajdujący się dzisiaj w muzeum w dukielskim pałacu. 
Bernard Mniszech, dwa lata później rozpoczął kształtowanie rezydencji typu palazzo in fortezza ${ }^{71}$. Najciekawszy okres $\mathrm{w}$ dziejach miasteczka wiązał się z poczynaniami Mniszchów: Józefa Wandalina, a zwłaszcza (lata 1764-1778) Jerzego Augusta Wandalina, wybitnego mecenasa sztuki ${ }^{72}$. Na krótko uczynili oni z Dukli jeden z najświetniejszych ośrodków artystycznych w kraju, z magnacką rezydencją dorównująca splendorem najświetniejszym ziemiańskim siedzibom na kresach Rzeczypospolitej ${ }^{73}$. Na plan pierwszy wysuwa się przebudowa rezydencji jako pałacu w typie entre cour et jardin, być może według projektu Jana Fryderyka Knöbla, z ogrodem dekorowanym rzeźbami wiązanymi z lwowskim artystą Fabianem Fesingerem. Nie mniej świetnym osiągnięciem okazała się gruntowna przebudowa kościoła parafialnego, po wstępnej fazie z lat 1742-1747 przeprowadzona ostatecznie w latach 1764-1765. W rezultacie powstało wybitne dzieło saskiego rokoka (niezidentyfikowany architekt pochodził zapewne z Drezna), z bogatym wystrojem kształtowanym przez znakomitych lwowskich artystów: malarza Stanisława Stroińskiego (słabo dziś zachowane freski), Piotra Polejowskiego (ołtarz główny), Jana Obrockiego (rzeźby) i zapewne Franciszka Olędzkiego (nagrobek Marii Amalii Mniszchowej). Bez poważniejszego udziału właścicieli - a co za tym idzie, na nieco niższym poziomie artystycznym - budowano eksponowany dzięki osi widokowej zespół bernardyński (1761-1764) ${ }^{74}$, upamiętniający XV-wieczną tradycję błog. Jana z Dukli.

Nie zabrakło skupiska ludności żydowskiej, notowanej od drugiej połowy XVII w. Gdy na przedmieściu spłonęła bożnica drewniana (1758), wzniesiono, być może ze wsparciem finansowym Mniszchów,

${ }^{71}$ Katalog zabytków..., s. 26; M. Proksa, Budownictwo obronno-rezydencjonalne ziemi przemyskiej i sanockiej (połowa XIV w. - połowa XVII w.), Przemyśl 1994, s. 219-224; M. Gosztyła, M. Proksa, Zamki Polski południowo-wschodniej, Przemyśl 1997, s. 36-38; S. Kołodziejski, Dukla, w: L. Kajzer, S. Kołodziejski, J. Salm, Leksykon zamków w Polsce, Warszawa 2001, s. 163; S. Kryciński, Bastiony w Dukli, „Magury” 2003, s. $116-122$.

72 E. Świeykowski, Monografia Dukli, Kraków 1903, s. 22, 126-130, passim; M. Horn, Mniszech Jerzy Wandalin, w: PSB, t. 21, Wrocław 1976, z. 3; M. Czaplińska, Mniszchowa z Brühlów Amalia, w: tamże; taż, Mniszech Józef Wandalin, w: tamże; E. Rudzki, Damy polskie XVIII wieku, Warszawa 1997; A. Żółkoś, Mecenat kulturalny Jerzego Augusta Wandalina Mniszcha w Dukli, Dukla 2012.

${ }^{73}$ T.S. Jaroszewski, Architektura doby oświecenia $w$ Polsce. Nurty $i$ odmiany, Wrocław 1971; tenże, Nurt późnobarokowy i rokokowy w architekturze polskiej doby oświecenia, w: Rokoko. Studia nad sztuka I połowy XVIII w. Materiaty sesji Stowarzyszenia Historyków Sztuki zorganizowanej wspólnie z Muzeum Ślaskim we Wrocławiu, Wroctaw, październik 1968, Warszawa 1970, s. 312.

74 B. Krasnowolski, Między Wschodem a Zachodem..., s. 184-189. 
murowana ${ }^{75}$ (dziś w stanie ruiny). Zapewne z początku XVIII w. pochodzi starsza część kirkutu ${ }^{76}$.

Przykładem niewielkiego miasta prywatnego niezwiązanego z siedzibą właściciela jest Brzesko (Brzeżek, Brzeg) ${ }^{77}$. Lokacyjne osadnictwo formowało się tu w trzech etapach. W XIII w. istniała lokacyjna, rycerska wieś Pomianowa (Pomianowa Wola) ${ }^{78}$, należąca przejściowo do dóbr staniąteckich benedyktynek. W drugim etapie, okresie kształtowania włości Spicymira Leliwity i zakładania Tarnowa, może przed 1331 r., możnowładca ten pozyskał tereny nad Uszwica, w sasiedztwie Pomianowej, i do $1344 \mathrm{r}$. osadził cztery wsie ${ }^{79}$, regularnie rozplanowane (il. 10), z nawsiami w dolinach potoków, rozłogiem ról w linii północpołudnie i granicami, które można wpisać w modularne prostokąty: dwie o powierzchniach po 24 łany, flankujące Pomianowa (Brzezowiec i Jasień), dwie 60-łanowe (Poręba Spytkowska i Okocin - dziś Okocim). Później, w etapie trzecim, założone zostało miasteczko Brzeżek, z centrum $^{80}$ na pagórku ponad brzegiem Uszwicy (stąd nazwa), przy zbiegu granic Brzezowca, Pomianowej Woli i Okocimia. Wchłonęło ono część uposażenia rolnego Brzezowca. Lokacja mogła być wynikiem przywileju królowej Jadwigi, która - na prośbę Spytka z Melsztyna - przeniosła jego wsie i miasta w 1385 r. na prawo niemieckie. Za data ta przemawia późniejszy o rok przywilej Władysława Jagiełły, zwalniający mieszczan Brzeżka od ceł w granicach Królestwa. Mielibyśmy zatem znowu opisywaną już sekwencję zdarzeń: po lokacjach wsi i wytyczeniu ich układów nastapiła lokacja miasta. Brzesko w dobrach rycerskich Leliwitów nie odegrało nigdy roli porównywalnej do Tarnowa, nie powstała tu siedziba właściciela, nie rozwinęła się murowana zabudowa.

$\mathrm{Na}$ zakończenie warto się zastanowić, w jakim stopniu i w jakich formach tradycje średniowiecznych lokacyjnych miast prywatnych rzutowały na miasta nowożytne. Omówione wyżej przykłady świadcza, że ważne cechy odróżniające nowożytne miasta prywatne od królewskich wykształcały się już w średniowieczu. Zasadniczą różnicą była

${ }^{75}$ Katalog zabytków..., s. 25-26; M. i K. Piechotkowie, Bramy nieba..., s. 419; T. Żychiewicz, Dukla, synagoga, dokumentacja naukowa, Kraków 1957, mps, PKZ, archiwum WKZ w Rzeszowie.

${ }^{76}$ M. Gosztyła, M. Proksa, Kirkuty Podkarpacia, Przemyśl 2001.

${ }_{77}$ Interpretacja źródeł pisanych: F. Sikora, Brzeżek, w: SHG, cz. 1, z. 2, Wrocław 1985, s. 256-260; W. Dworzaczek, dz. cyt., s. 80-81.

${ }_{78}$ Pomianowa, niepublikowane wypisy źródłowe w Pracowni SHG.

${ }^{79}$ W. Dworzaczek, dz. cyt., s. 81.

${ }^{80} \mathrm{Z}$ analizy modularnej wynika, że zastosowany tu system miar to stopy wartości $0,30 \mathrm{~m}$, pręty $=4,50 \mathrm{~m}$ i sznury $=45 \mathrm{~m}$; B. Krasnowolski, Lokacyjne uktady..., cz. 2, s. $36-40$ i il. 40 . 
Il. 10. Brzesko i otaczające je wsie, analiza rozmierzenia lokacyjnego; oprac. własne autora.

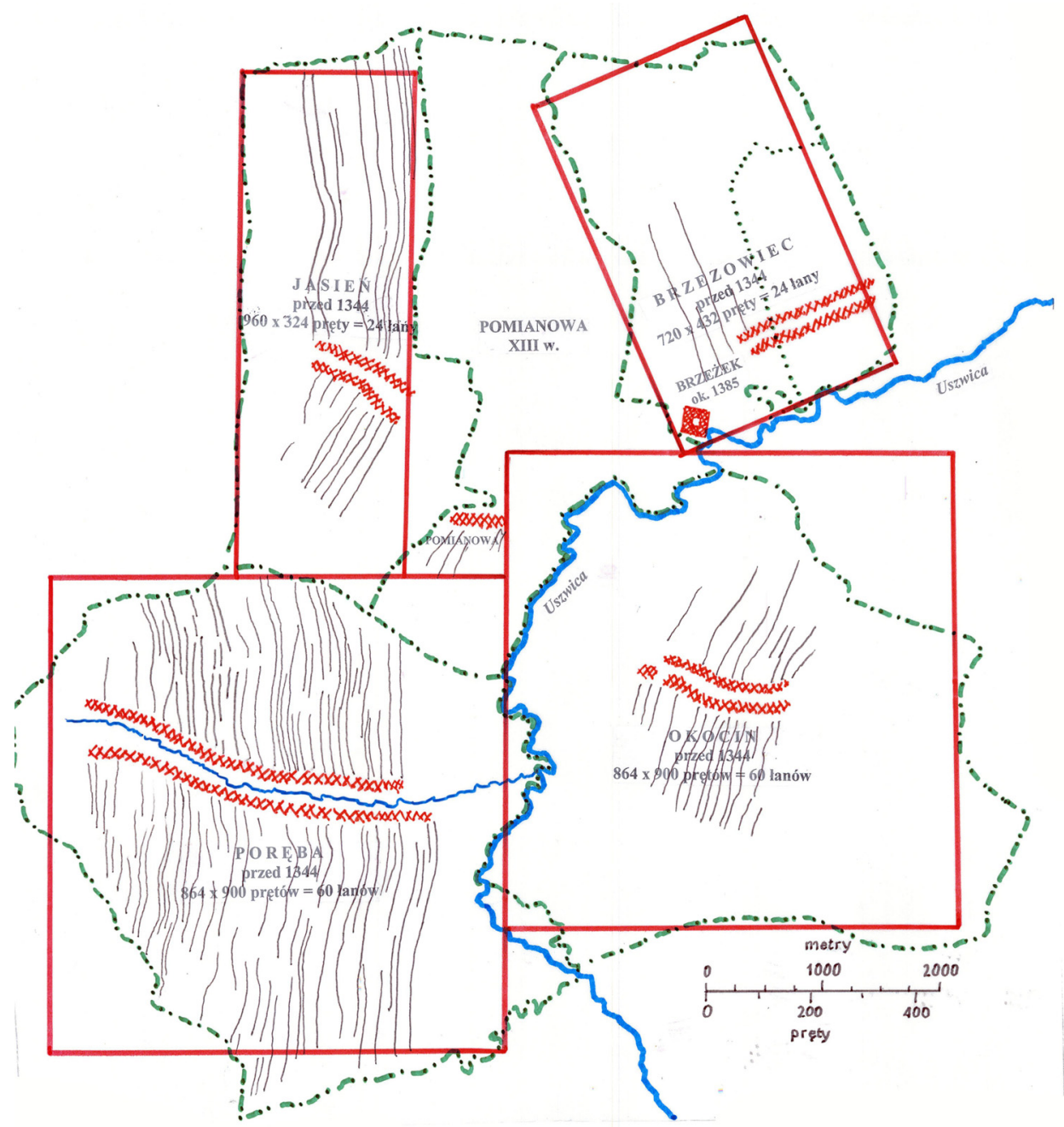

odmienność przesłanek kształtujących układy przestrzenne i związana z nimi architekturę: w średniowieczu decydowały motywy ekonomiczne, w nowożytności - gdy rozwijały się modele miasta idealnego - znaczenie co najmniej równorzędne miały względy estetyczne, wymagające kompozycji osiowych, wiążących w jednolitą całość miasto i rezydencję.

Rozwój średniowiecznych miast w dobie nowożytnej bywał niekiedy podporządkowywany owym zasadom kompozycyjnym (spośród omówionych przykładów najlepiej widać to w relacji między pałacem 
Piotra Myszkowskiego na Mirowie a miastem Książ Wielki), częściej jednak kompozycja rezydencji nie miała z miastem żadnych relacji (Pilica, Dukla). Powiązania widokowe mogły się pojawiać także wówczas, gdy w sasiedztwie średniowiecznej, przekształcanej siedziby rycerskiej zakładano nowożytne miasto. Przykładem może być Nowy Wiśnicz Stanisława Lubomirskiego z lat około 1616 - około $1640^{81}$, ze średniowiecznym zamkiem Kmitów przekształconym we włoskie założenie typu palazzo in fortezza.

Związane z fundacjami kościelnymi - upamiętniającymi rangę fundatorów-patronów - dążenie do stwarzania autonomicznej względem władz diecezjalnych kościelnej struktury organizacyjnej, widoczne np. w poczynaniach Jana Zamoyskiego w Zamościu, zaznaczyło się już np. w późnośredniowiecznym Tarnowie. Kilkanaście lat po uzyskaniu przez kościół parafialny statusu kolegiaty władzy tarnowskich prepozytów podporządkowano kilka sąsiednich parafii. Średniowieczne świątynie - z kolegiata tarnowską na czele - stawały się rodowymi nekropoliami, co w dobie nowożytnej akcentowały okazałe nagrobki.

Tradycja niewielkich miast prywatnych, wytyczanych według średniowiecznych wzorów i zgodnie ze średniowieczna praktyka, nie została całkowicie wyparta przez wzory miast idealnych, lecz trwała nadal w szeregu skromniejszych realizacji, jak Zakliczyn nad Dunajcem (przekształcony w 1558 r. z benedyktyńskiej wsi lokacyjnej Opatkowice staraniem Wawrzyńca Spytka Jordana) ${ }^{82}$ czy Jordanów, osadzony w 1564 r. na surowym korzeniu przez tegoż możnowładcę.

\section{Bibliografia}

Bałaban M., Studia historyczne, Warszawa 1927.

Bogdanowski J., Obronna wieża mieszkalna dworu Karwacjanów w Gorlicach, $\mathrm{w}$ : Architektura rezydencjonalna i obronna województwa rzeszowskiego $w$ świetle badań ratowniczych prowadzonych w 25-leciu PRL. Materiaty $z$ sesji naukowej, Łańcut 9-10 maja 1970, Łańcut 1972, s. 77-83.

Cetera A., Okoński J., Grodzisko wczesnośredniowieczne w Zawadzie, gm. Tarnów, w: Badania archeologiczne w województwie tarnowskim w 1988 roku, Tarnów 1990, s. 23-27.

${ }^{81}$ P.S. Szlezynger, Nowy Wiśnicz. Historia, architektura, konserwacja, Kraków 2013.

${ }^{82}$ B. Krasnowolski, Zabytkowy zespót urbanistyczny Zakliczyna i problemy jego ochrony konserwatorskiej, „Rocznik Tarnowski” 1991; tenże, Lokacyjne układy..., cz. 1, s. 157, il. 17. 
Cetera A., Okoński J., Grodzisko wczesnośredniowieczne w Zawadzie, gm. Tarnów, w: Badania archeologiczne w województwie tarnowskim w 1989 roku, Tarnów 1991, s. 30-32.

Cetera A., Okoński J., Grodzisko w Zawadzie - dziesięć lat później, „Rocznik Tarnowski" 1994, s. 287-310.

Cetera A., Okoński J., Wiślański gród pod Tarnowem, „Z Otchłani Wieków” 50, 1984, z. 3-4, s. 166-169.

Chrzanowski T., Kornecki M., Sztuka Ziemi Krakowskiej, Kraków 1982.

Chrzanów. Studia z dziejów miasta i regionu do roku 1939, t. 1, t. 2, cz. 1, Chrzanów 1998, 1999.

Czaplińska M., Mniszchowa z Brühlów Amalia, w: PSB, t. 21, Wrocław 1976, z. 3.

Czaplińska M., Mniszech Józef Wandalin, w: PSB, t. 21, Wrocław 1976, z. 3.

Dayczak-Domanasiewicz M., Uwagi o architekturze renesansowych dworów $w$ Jeżowie $i$ Szymbarku $w$ powiecie gorlickim, w: Architektura rezydencjonalna i obronna województwa rzeszowskiego, Łańcut 1972.

Dunin-Wasowicz A., Pomiar gruntu $w$ Koronie $w$ XV-XVIII w., Warszawa 1994.

Dutkiewicz J.E., Materiały źródłowe do budowy murów obronnych Tarnowa z lat 1513-1544, „Rocznik Historii Sztuki” 1, 1956, s. 237-301.

Dutkiewicz J.E., Tarnów, Warszawa 1954.

Dworaczyński E., Nowe ślady pierwszej fazy zamku na Górze Św. Marcina, $\mathrm{w}$ : Badania archeologiczne w województwie tarnowskim $w 1985$ roku, Tarnów 1986, s. 12-14.

Dworaczyński E., Okoński J., Zamek tarnowski, Tarnów 1986.

Dworzaczek W., Leliwici tarnowscy. Z dziejów możnowładztwa małopolskiego, wiek XIV-XV, Warszawa 1971.

Fischinger A., Santi Gucci, architekt i rzeźbiarz królewski XVI wieku, Kraków 1969.

Fischinger A., Ze studiów nad twórczościa Bartłomieja Berrecciego i jego warsztatem: nagrobki Szydtowieckich $i$ Tarnowskich, „Folia Historiae Atrium" 10, 1974, s. 117-135.

Gosztyła M., Proksa M., Kirkuty Podkarpacia, Przemyśl 2001.

Gosztyła M., Proksa M., Zamki Polski południowo-wschodniej, Przemyśl 1997.

Horn M., Mniszech Jerzy Wandalin, w: PSB, t. 21, Wrocław 1976, z. 3.

Janczykowski J., Zamek Jerzego Zbaraskiego w Pilicy - rezydencja „militaris”, w: Dzieło sztuki a konserwacja. Materiały 52 Ogólnopolskiej Sesji Naukowej SHS, Kraków 20-22 XI 2003, Kraków 2004, s. 173-193.

Janczykowski J., Zamek $w$ Pilicy na tle architektury rezydencjonalno-obronnej $w 1$ połowie XVII w. w Polsce, Kraków 2015, mps pracy doktorskiej, Politechnika Krakowska.

Jaroszewski T.S., Architektura doby oświecenia w Polsce. Nurty i odmiany, Wrocław 1971.

Jaroszewski T.S., Nurt późnobarokowy i rokokowy w architekturze polskiej doby oświecenia, w: Rokoko. Studia nad sztuka I połowy XVIII w. Materiały sesji 
Stowarzyszenia Historyków Sztuki zorganizowanej wspólnie z Muzeum Ślaskim we Wrocławiu, Wrocław, październik 1968, Warszawa 1970.

Jodłowski A., Pradzieje i wczesne średniowiecze okolic Tarnowa, w: Tarnów. Dzieje miasta i regionu, t. 1, red. F. Kiryk, Z. Ruta, Tarnów 1981.

Kamiński A., Nieznane karty z dziejów Dukli, w: Prace z dziejów Polski feudalnej ofiarowane Romanowi Grodeckiemu w 70 rocznice urodzin, Warszawa 1960, s. 401-430.

Katalog zabytków sztuki w Polsce, seria nowa, t. 1: Województwo krośnieńskie, z. 1: Krosno, Dukla i okolice, oprac. E. Śnieżyńska-Stolotowa, F. Stolot, Warszawa 1977.

Kiryk F., Chrzanów na przełomie średniowiecza $i$ czasów nowożytnych, „Studia Historyczne" 39, 1996, z. 4.

Kiryk F., Miasta regionu tarnowskiego do końca XVI w., w: Tarnów. Dzieje miasta $i$ regionu, t. 1, red. F. Kiryk, Z. Ruta, Tarnów 1981.

Kiryk F., Pozostate miasta regionu olkuskiego, w: Dzieje Olkusza i regionu olkuskiego, red. F. Kiryk, R. Kołodziejczyk, Kraków 1978.

Kiryk F., Rozwój urbanizacji Małopolski XIII-XV w. Województwo krakowskie (powiaty południowe), Kraków 1985.

Kiryk F., Z dziejów miast w zachodniej części ziemi bieckiej do 1520 r., w: Nad rzeka Ropa, cz. 3: Szkice historyczne, red. F. Kiryk, Kraków 1968.

Kołodziejski S., Dukla, w: L. Kajzer, S. Kołodziejski, J. Salm, Leksykon zamków w Polsce, Warszawa 2001, s. 163.

Kołodziejski S., Średniowieczne rezydencje obronne możnowładztwa na terenie województwa krakowskiego, Kraków 1994.

Krakowski P., Pomnik nagrobny ks. Ostrogskich (w Tarnowie), „Studia Renesansowe" 2, 1957, s. 263-299.

Krasnowolski B., Ekspozycja muzealna jako interpretacja historycznych $i$ artystycznych wartości ratusza $w$ Tarnowie, „Arkusze Muzealne” (Nowy Sacz) 1975.

Krasnowolski B., Gotyckie stalle bernardyńskie z Tarnowa, „Rocznik Tarnowski” 1991/1992, s. 25-30.

Krasnowolski B., Krakowskie warsztaty budowlane $i$ kamieniarskie na przełomie średniowiecza i nowożytności, „Rocznik Krakowski” 72, 2006.

Krasnowolski B., Lokacyjne układy urbanistyczne na obszarze Ziemi Krakowskiej $w$ XIII $i$ XIV wieku, cz. 1-2, Kraków 2004.

Krasnowolski B., Między Wschodem a Zachodem. Studia nad historia i sztuka pogranicza polsko-łemkowskiego, Torun 2010.

Krasnowolski B., Zabytki i wartości kulturowe, w: Chrzanów. Studia z dziejów miasta i regionu do roku 1939, t. 2, cz. 1, Chrzanów 1999.

Krasnowolski B., Zabytkowy zespót urbanistyczny Zakliczyna i problemy jego ochrony konserwatorskiej, „Rocznik Tarnowski” 1991.

Krasnowolski B., Zasady lokacyjnego rozmierzenia wsi podhalańskich miedzy Nowym Targiem a Krościenkiem, w: Późne średniowiecze w Karpatach polskich, red. J. Gancarski, A. Muzyczuk, Krosno 2007, s. 123-137.

Kryciński S., Bastiony w Dukli, „Magury” 2003, s. 116-122. 
Kumor B., Prepozytura tarnowska, „Archiwa, Biblioteki i Muzea Kościelne” 12, 1966, s. 236-238, 241-242, 245-249.

Kurtyka J., Ksiàz Wielki, w: Stownik historyczno-geograficzny województwa krakowskiego w średniowieczu, cz. 3, z. 2, Kraków 1997, s. 291-313.

Laberschek J., Gorlice, w: Stownik historyczno-geograficzny województwa krakowskiego w średniowieczu, cz. 1, Wrocław 1980, s. 792-799.

Leńczyk G., Obronny dwór średniowieczny w Ksiqżu Wielkim w pow. miechowskim, „Z Otchłani Wieków” 17, 1948, z. 5-6, s. 81-82.

Leo A., Tarnowskie kościoty, Tarnów 2000.

Leszczyńska-Skrętowa Z., Bobowa, w: Stownik historyczno-geograficzny województwa krakowskiego w średniowieczu, cz. 1, Wrocław 1980, s. 140-146.

Leszczyńska-Skrętowa Z., Chrzanów, w: Stownik historyczno-geograficzny województwa krakowskiego w średniowieczu, cz. 1, Wrocław 1980, s. 379 -383 .

Loesch H. von, Die frankische Hufe, „Zeitschrift des Vereins für Geschichte Schlesiens" 61, cz. 1-2, 1927, 1929.

Marszałek J., Katalog grodzisk $i$ zamczysk w Karpatach, Warszawa 1993.

Mateszew S., Sikora F., Osadnictwo $i$ stosunki wtasnościowe $w$ regionie tarnowskim do końca XVI wieku, w: Tarnów. Dzieje miasta i regionu, t. 1, red. F. Kiryk, Z. Ruta, Tarnów 1981.

Moskal K., In castro nostro tarnoviensi. Zamek tarnowski jako rezydencja, warownia $i$ centrum administracyjno-gospodarcze dla dóbr tarnowskich, Tarnów 2001.

Motyka Z., Kasztelania chrzanowska, w: Chrzanów. Studia z dziejów miasta i regionu do roku 1939, t. 1, Chrzanów 1998, s. 43-57.

Nowosad-Grylowa M., Badania archeologiczne na zamku $w$ Tarnowie, w: Polonia Minor medii aevii, red. Z. Woźniak, J. Gancarski, Kraków-Krosno 2003, s. 517-522.

Piechotkowie M. i K., Bramy nieba. Bożnice murowane na ziemiach dawnej Rzeczypospolitej, Warszawa 1999.

Piechotkowie M. i K., Oppidum Judaeorum. Żydzi w przestrzeni miejskiej dawnej Rzeczypospolitej, Warszawa 2004.

Proksa M., Budownictwo obronno-rezydencjonalne ziemi przemyskiej i sanockiej (połowa XIV w. - połowa XVII w.), Przemyśl 1994.

Rudzki E., Damy polskie XVIII wieku, Warszawa 1997.

Schulz A.M., Giammaria Mosca called Padovano. A Renaissance Sculptor in Italy and Poland, University Park (PA) 1998.

Sikora F., Brzeżek, w: Stownik historyczno-geograficzny województwa krakowskiego $w$ średniowieczu, cz. 1, z. 2, Wrocław 1985, s. 256-260.

Sikora F., Dukla, w: Stownik historyczno-geograficzny województwa krakowskiego $w$ średniowieczu, cz. 1, z. 4, Kraków 1986, s. 625-629.

Sikora F., Dukla Stara albo Przedmieście Dukielskie, w: Stownik historyczno-geograficzny województwa krakowskiego $w$ średniowieczu, cz. 1, z. 4, Kraków 1986, s. 639-631. 
Sinko-Popielowa K., Świszczowski S., Dwór obronny w Szymbarku, „Biuletyn Historii Sztuki i Kultury" 6, 1938.

Siwiec B.P., Bernardyni tarnowscy latach 1459-1939. Zarys dziejów klasztoru Zakonu Braci Mniejszych w Tarnowie, Tarnów 1999.

Stoksik J., Wtaściciele Chrzanowa od poczatku XVII do 1. pot. XIX w. i ich stosunek do miasta, w: Chrzanów. Studia z dziejów miasta i regionu do roku 1939, t. 1, Chrzanów 1998.

Szczebak W., Tarnowska bazylika katedralna. Dzieje i sztuka, Tarnów 2007.

Szlezynger P.S., Nowy Wiśnicz. Historia, architektura, konserwacja, Kraków 2013.

Szymański J., Nauki pomocnicze historii, Warszawa 1983.

Świeykowski E., Monografia Dukli, Kraków 1903.

Tabaka Z., Zarys dziejów miasteczka Bobowej do 1914 r., w: Nad rzekq Ropa, cz. 3: Szkice historyczne, red. F. Kiryk, Kraków 1968.

Tarnów. Dzieje miasta i regionu, t. 1, red. F. Kiryk, Z. Ruta, Tarnów 1981.

Tomkowicz S., Powiat grybowski, „Teka Grona Konserwatorów Galicji Zachodniej” 1900, nr 1.

Trajdos E., Treści ideowe nagrobka Barbary z Rożnowa katedrze tarnowskiej, „Archiwa, Biblioteki i Muzea Kościelne” 9, 1964, s. 47-64.

Trajdos E., Portal południowy katedry w Tarnowie, „Biuletyn Historii Sztuki” 22, 1960, nr 2, s. 179-184.

Trusz M., Synagoga Stara w Tarnowie, „Rocznik Tarnowski” 1991/1992, s. $31-39$.

Wojas Z., Chrzanów średniowieczny i nowożytny do połowy XVII w., w: Chrzanów. Studia z dziejów miasta i regionu do roku 1939, t. 1, Chrzanów 1998, s. $61-110$.

Wójcikiewicz M., Zarys rozwoju przestrzennego miasta Bobowej, „Teka Komisji Urbanistyki i Architektury" 16, 1982, s. 119-124.

Zacny F., Żydzi w Chrzanowie w XVII i XVIII wieku, w: Chrzanów. Studia z dziejów miasta i regionu do roku 1939, t. 1, Chrzanów 1998, s. 283-306.

Zarębska T., Badania historyczno-urbanistyczne metoda analiz przestrzennych, KHKM, t. 43, 1995, nr 1, s. 15-32.

Żółkoś A., Mecenat kulturalny Jerzego Augusta Wandalina Mniszcha w Dukli, Dukla 2012.

Żychiewicz T., Dukla, synagoga, dokumentacja naukowa, Kraków 1957, mps, PKZ, archiwum WKZ w Rzeszowie. 
Bogusław Krasnowolski

Spacial layouts of private towns in Lesser Poland. Selected examples (Summary)

The paper focuses on selected private medieval towns of Lesser Poland, including their transformation in the modern era (with emphasis placed on the tendency to convert the parish church into a family mausoleum; an example can be the collegiate church in Tarnów in the $16^{\text {th }}-17^{\text {th }}$ century). The number of towns founded by Lesser Poland knights in the period of medieval urban and rural colonisation was higher than the number of centres founded by monarchs; these initiatives coincided with the formation of new magnate elites during the reign of Władysław the Elbow-high and Casimir the Great. Foundations of towns were often preceded by foundations of villages, with towns separated from their area later on (Tarnów, Dukla, Brzesko, probably also Pilica).

The material is divided into three groups on the basis of the relationship between the town and the residence of the owner. The first group is composed of towns founded in a single process - often lasting many years - of founding nearby villages and developing the residence of the owner (Tarnów, probably also Bobowa, Gorlice, Szymbark, and Chrzanów). The second group encompasses towns whose foundation was not concurrent with the creation of the residence, which in the modern period developed into an impressive palace establishment (Książ Wielki, Pilica, Dukla). The third group consists of small towns of secondary importance for family estates and therefore not requiring the existence of the residence of the owner (Brzesko).

Bogusław Krasnowolski - (ur. 1943), dr hab., prof. Uniwersytetu Papieskiego Jana Pawła II w Krakowie. Historyk sztuki, habilitacja w zakresie historii średniowiecznej na Akademii Pedagogicznej w Krakowie. Od 1990 r. wiceprzewodniczący Społecznego Komitetu Odnowy Zabytków Krakowa. Autor wielu prac naukowych z dziedziny historii sztuki i urbanistyki oraz ochrony zabytków, współautor programów ochrony konserwatorskiej Krakowa, członek Polskiego Komitetu Narodowego ICOMOS. E-mail: bkrasnowol@interia.pl. 